\title{
Geothermal Boreholes in Poland-Overview of the Current State of Knowledge
}

\author{
Tomasz Sliwa *, Aneta Sapińska-Śliwa, Andrzej Gonet, Tomasz Kowalski and Anna Sojczyńska \\ Laboratory of Geoenergetics, AGH University of Science and Technology in Krakow, al. Adama Mickiewicza 30, \\ 30-059 Krakow, Poland; ans@agh.edu.pl (A.S.-Ś.); gonet@agh.edu.pl (A.G.); tkowal@agh.edu.pl (T.K.); \\ anbieda@agh.edu.pl (A.S.) \\ * Correspondence: sliwa@agh.edu.pl; Tel.: +48-12-617-22-17
}

Citation: Sliwa, T.; Sapińska-Śliwa, A.; Gonet, A.; Kowalski, T.;

Sojczyńska, A. Geothermal Boreholes in Poland-Overview of the Current State of Knowledge. Energies 2021, 14, 3251. https://doi.org/10.3390/ en14113251

Academic Editor: Javier

F. Urchueguía

Received: 1 March 2021

Accepted: 27 May 2021

Published: 2 June 2021

Publisher's Note: MDPI stays neutral with regard to jurisdictional claims in published maps and institutional affiliations.

Copyright: (c) 2021 by the authors. Licensee MDPI, Basel, Switzerland. This article is an open access article distributed under the terms and conditions of the Creative Commons Attribution (CC BY) license (https:// creativecommons.org/licenses/by/ $4.0 /)$.

\begin{abstract}
Geothermal energy can be useful after extraction from geothermal wells, borehole heat exchangers and/or natural sources. Types of geothermal boreholes are geothermal wells (for geothermal water production and injection) and borehole heat exchangers (for heat exchange with the ground without mass transfer). The purpose of geothermal production wells is to harvest the geothermal water present in the aquifer. They often involve a pumping chamber. Geothermal injection wells are used for injecting back the produced geothermal water into the aquifer, having harvested the energy contained within. The paper presents the parameters of geothermal boreholes in Poland (geothermal wells and borehole heat exchangers). The definitions of geothermal boreholes, geothermal wells and borehole heat exchangers were ordered. The dates of construction, depth, purposes, spatial orientation, materials used in the construction of geothermal boreholes for casing pipes, method of water production and type of closure for the boreholes are presented. Additionally, production boreholes are presented along with their efficiency and the temperature of produced water measured at the head. Borehole heat exchangers of different designs are presented in the paper. Only 19 boreholes were created at the Laboratory of Geoenergetics at the Faculty of Drilling, Oil and Gas, AGH University of Science and Technology in Krakow; however, it is a globally unique collection of borehole heat exchangers, each of which has a different design for identical geological conditions: heat exchanger pipe configuration, seal/filling and shank spacing are variable. Using these boreholes, the operating parameters for different designs are tested. The laboratory system is also used to provide heat and cold for two university buildings. Two coefficients, which separately characterize geothermal boreholes (wells and borehole heat exchangers) are described in the paper.
\end{abstract}

Keywords: geothermal wells; borehole heat exchangers; geothermal boreholes; geothermal waters; geothermal energy; geoenergetics

\section{Introduction}

Renewable energy sources are increasingly used around the world. These include geothermal energy, which is exploited by geothermal boreholes. Two types of boreholes are used: geothermal wells (production and injection) and borehole heat exchangers (BHE).

A geothermal well is a borehole that allows production or injection of geothermal waters from both deep and shallow aquifers. The deep layers are used for production and injection of geothermal waters, whereas the shallow layers are mostly used as lowtemperature waters for geothermal heat pumps.

Geothermal boreholes may be vertical, inclined or directional. They can also (earlier) fulfill an exploratory role. As a rule, the construction of the first geothermal borehole must take into account detailed specialist tests, including geophysical and hydrogeological research of the aquifer with geothermal water or thermal response tests in the case of BHEs [1]. In addition, the heat accumulated in the greater depths of the rock mass (mostly between 3000 and $6000 \mathrm{~m}$ [2]) can be exploited using HDR and EGS systems [3,4]. Hydraulic frac- 
turing is a procedure for greater consumption of geothermal energy from such significant depths [2]. An increasing amount of EGS research demonstrates its development [5-8].

(Very) low-temperature heat can be used by shallow geothermal boreholes known as borehole heat exchangers (BHEs). Borehole heat exchangers are becoming more and more popular. They are used in heating systems or heating and cooling installations with heat pumps [9]. Exploiting the heat of the shallow layers, besides geothermal heat in the Earth, also includes solar heat, which is accumulated in the surface layers as a result of solar radiation and higher temperatures of atmospheric air. The system's basic parameter is the obtainable heating power. This parameter is affected mainly by the depth, the number and the location of borehole heat exchangers, exploiting parameters and construction of the BHE [10]. The topic of borehole heat exchangers design is also considered by Aresti et al. 2018 [11]. It is also necessary to mention the so-called ground-coupled heat exchangers (GSHE) or hybrid systems for space heating/cooling [12] with heat/cold storage in the rock mass. In addition, there is a growing interest regarding the geothermal resources available at shallow depths beneath urban areas [13]. Computer modeling and simulations [14-16] are used to properly design the installations of borehole heat exchangers.

One of the most important tests performed to understand the properties of rocks, and simultaneously the appropriate selection of borehole heat exchanger's design is the Thermal Response Test-TRT [17,18]. The main parameters which can be determined using TRT are effective thermal conductivity and borehole resistance [19]. Currently, Thermal Response Tests are being conducted in an increasingly advanced form [20,21].

New ideas for using geothermal boreholes have been described in the last few years. Examples include the geothermal energy-assisted natural gas hydrate recovery method, which can simultaneously exploit geothermal energy and natural gas hydrates by injecting water into a geothermal heat exchange well, proposed by Liu et al. [22]. Dai et al. described a deep geothermal well with a downhole coaxial open-loop design [23]. Multilateral wells can be also used for heat extraction in enhanced geothermal systems [24].

Every year more papers describe the use of abandoned oil and gas wells. Advanced geothermal utilizations have been described by Nian and Cheng [25]. The utilization of closed mines is also mentioned in the scientific articles [26,27]. Recently, many publications have also been made regarding the use of new heat carriers in geothermal systems, for instance using $\mathrm{CO}_{2}$, as indicated by Esteves et al. [28] and Shi et al. [29]. Various organic fluids were analyzed by Cheng et al. [30] and Van Erdeweghe [31].

Currently in Poland hydrogeothermal resources are utilized, for which the energy carrier is hot groundwater extracted from the geothermal wells [32] with various economic benefits [33]. Additionally, the number of geothermal heat pumps based on borehole heat exchangers grows every year. The Laboratory of Geoenergetics conducts research on the effectiveness of various borehole solutions for very low-temperature heat extraction. Under similar geological and hydrogeological conditions, 19 BHEs were drilled. Each of them has a different design. Thermal Response Tests are ongoing to identify the most energy-efficient design and the optimal operating parameters, primarily the flow rate of the heat carrier [19]. An energy pile was also studied in the Laboratory. The combination of the load-bearing pile with the borehole heat exchanger gives double the benefit-it increases the load capacity of the rock mass and provides a source of heat/cold [34].

Development in the field of geothermal wells is stimulated by the oil and gas industry. New solutions in drilling and borehole engineering can often be adapted to suit geothermal solutions.Examples include drilling using pads (shale gas/oil), and horizontal drilling, which are becoming some of the most influential innovations in the oil and gas industry of recent years. Those methods have become the standard for increasingly efficient exploitation, and it is expected that they will become more widespread. In addition, previously exploited oil wells can be adapted for geothermal purposes, e.g., as deep borehole heat exchangers. 


\section{Materials and Methods}

Effective exploration and sharing of geothermal water resources is possible across modern technology for drilling. At present, the rotary method with the right circulation of the mud is used [1].

\subsection{Materials Used in Geothermal Wells}

The casing pipes are usually made of steel, and therefore are susceptible to corrosion. While selecting the type of steel used for casing pipes, one should avoid carbon steel and low-alloy steel, because they are highly vulnerable to corrosion. In many cases non-alloyed steel with high strength, such as J-55 (Pyrzyce GT-4) and N-80 (LidzbarkWarmiński GT-1), is used [35].

In recent years, lining the inside of steel pipes with plastic has found wide application. Fiberglass pipes are also used. An example of steel pipes with an inner coating are Pyrzyce GT-2 and Pyrzyce GT-4 boreholes [36], as well as Torun TG- 1 where fiberglass pipes were used in the construction [37]. Such applications are used in order to reduce unfavorable processes in geothermal wells, such as corrosion [35,38].

There are many methods limiting processes and results of corrosion, as well as precipitation of secondary mineral substances in geothermal installations. They aim to recover production parameters in geothermal systems. These methods include: application of inhibitors, soft acidizing treatments and processes using non-organic and organic acid solutions [39].

In geothermal wells, Class $\mathrm{G}$ cement slurries with various additives and admixtures are most commonly used [40-42]. Most often silica flour is added in a quantity varying from 20 to even $100 \%$ BWOC (by weight of cement) together with additives and admixtures depending on the need to achieve the appropriate parameters of fresh cement slurry. Additives and admixtures include bentonite, carboxymethylcellulose or lime [40,41]. Another type of cement used in geothermal drilling is Class A cement [43]. The literature also includes the use of Class F and Class J cements in geothermal systems [41].

\subsection{List of Geothermal Wells with Theirparameters in Poland}

This subsection presents a list of geothermal borehole parameters in Poland (Table 1). Presented parameters such as: borehole name, year of construction, depth, production or injection rate, aquifer opening, geothermal water temperature at the head, borehole type, borehole purpose, spatial orientation, construction material, borehole bottom.

In Poland new boreholes are most often drilled for geothermal wells. In Table 1, those are specified as type "New". Boreholes drilled for other purposes, or geothermal wells made much earlier, in which reconstruction and adaptation works are necessary for the needs of obtaining geothermal water, are specified as type "Archival" in Table 1.

Table 1 does not include boreholes in: Dẹbica GT-1, Lądek Zdrój LZT-1, Sękowa GT-1 and others due to the lack of data in available publications. 
Table 1. Collective data on geothermal borehole parameters in Poland (based on [37-39,44-86]).

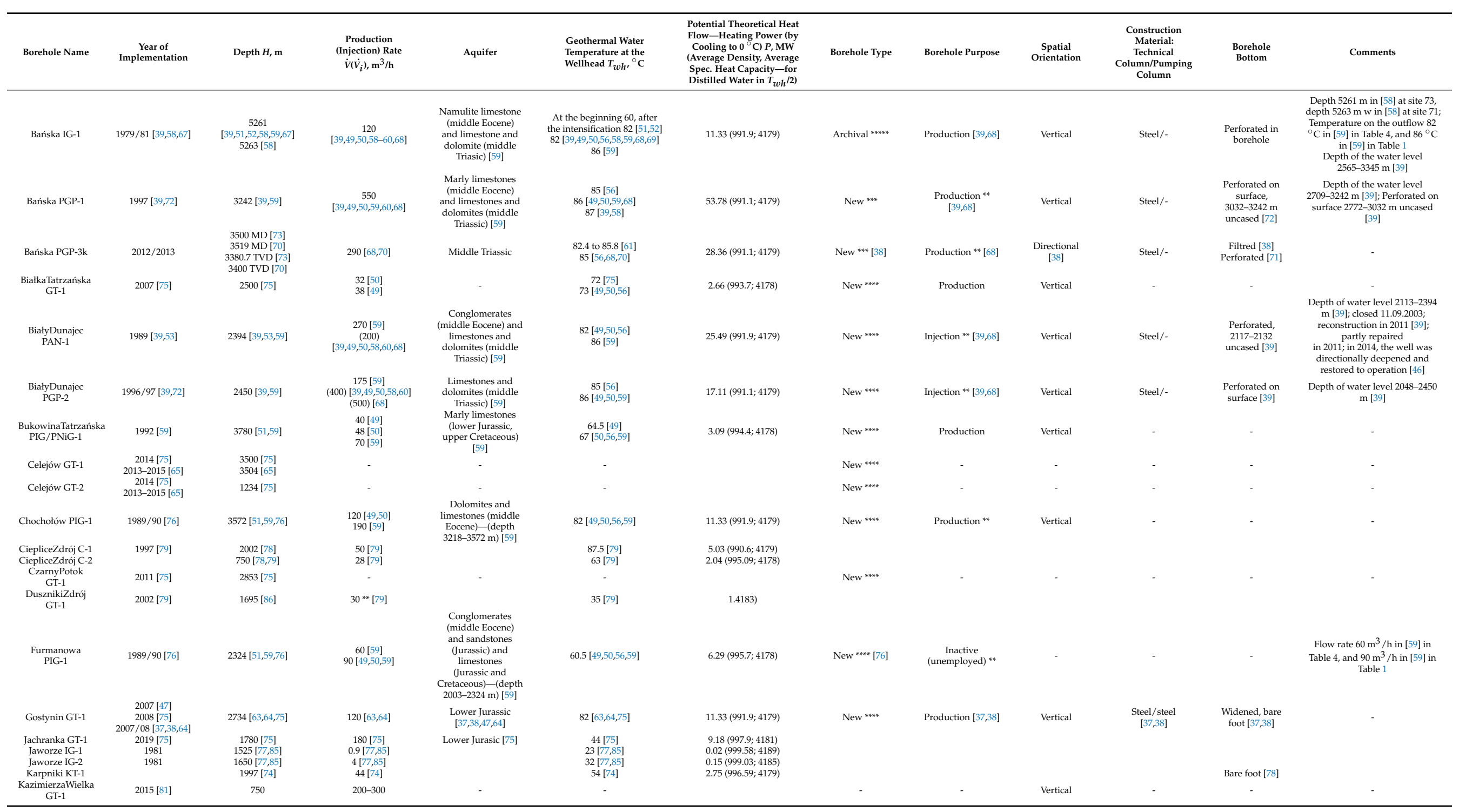


Table 1. Cont

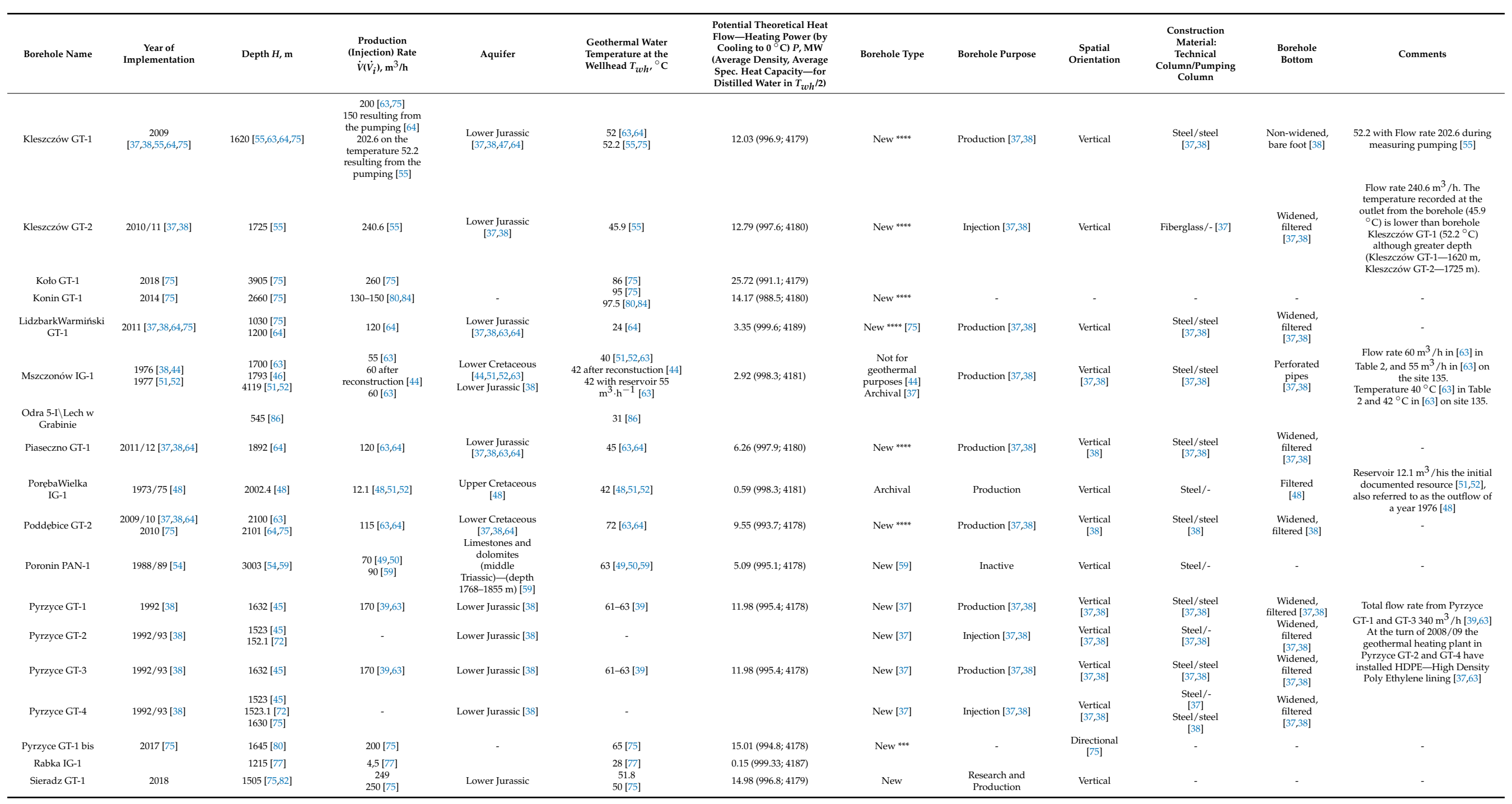


Table 1. Cont

\begin{tabular}{|c|c|c|c|c|c|c|c|c|c|c|c|c|}
\hline Borehole Name & $\begin{array}{c}\text { Year of } \\
\text { Implementation }\end{array}$ & Depth $H, \mathrm{~m}$ & $\begin{array}{c}\text { Production } \\
\text { (Injection) Rate } \\
\dot{v}\left(\dot{V}_{i}\right), \mathrm{m}^{3} / \mathrm{h}\end{array}$ & Aquifer & $\begin{array}{l}\text { Geothermal Water } \\
\text { Temperature at the } \\
\text { Wellhead }^{\text {wwh }}{ }^{\circ} \mathrm{C}\end{array}$ & 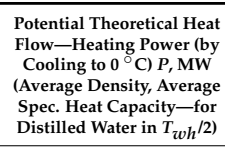 & Borehole Type & Borehole Purpose & $\begin{array}{c}\text { Spatial } \\
\text { Orientation }\end{array}$ & $\begin{array}{c}\text { Construction } \\
\text { Materiali: } \\
\text { Technical } \\
\text { Column/Pumping } \\
\text { Column }\end{array}$ & $\begin{array}{c}\text { Borehole } \\
\text { Bottom }\end{array}$ & Comments \\
\hline SiwaWoda IG-1 & $1972 / 73[76]$ & $856[51,59]$ & $4[49,50,59]$ & $\begin{array}{l}\text { conglomerates } \\
\text { (middle Ecoene) } \\
\text { and sandstones } \\
\text { (Jurassic and } \\
\text { limestones } \\
\text { (Jurassicand } \\
\text { Cretaceous- -depth } \\
\text { 2003-2324 m) [59] }\end{array}$ & $20[49,50,59]$ & $0.09(999.8 ; 4192)$ & Archival $1 * * *+* *$ & $\begin{array}{c}\text { Inactive } \\
\text { (unemployed) ** } \\
{[49]}\end{array}$ & & - & & - \\
\hline Skierniewice GT-1 & 1990/91 [39] & $3001[39]$ & $\begin{array}{l}70[39] \\
(13)[39]\end{array}$ & $\begin{array}{l}\text { Sandstones, } \\
\text { siltstones, claystones } \\
\text { (Lower Jurassic) } \\
\text { depth 2875-2941 m } \\
\text { [39] } \\
\text { Lower Jurassic [72] }\end{array}$ & $69.2[39]$ & $5.59(994.1 ; 4178)$ & New $* * * *[39]$ & Inactive & Vertical & - & $\begin{array}{c}\text { Filtered } \\
{[39]}\end{array}$ & 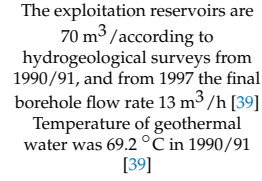 \\
\hline Skierniewice GT-2 & 1996/97 [39] & $2900[39]$ & $86.6[39]$ & $\begin{array}{c}\text { Lower Jurassic depth } \\
2771-2886 \mathrm{~m}[39] \\
\text { Lower Jurassic [72] }\end{array}$ & $57.5[39]$ & $5.76(996.0 ; 4179)$ & New $* * * *$ [39] & Inactive & Vertical & - & $\begin{array}{l}\text { Widened, } \\
\text { filtered [39] }\end{array}$ & $\begin{array}{l}\text { Flow rate: } 86.6 \mathrm{~m}^{3} / \mathrm{h} \text { with } \\
\text { temperature } 57.5^{\circ} \mathrm{C}[39]\end{array}$ \\
\hline $\begin{array}{l}\text { Sochaczew GT-1 } \\
\text { Staniszów ST-1 }\end{array}$ & 2018 & $\begin{array}{l}1540[75] \\
1501[74]\end{array}$ & $\begin{array}{l}\text { Min. 180 } \\
20.5[74]\end{array}$ & 44 [75] & $37.3[74]$ & $\begin{array}{l}9.18(997.9 ; 4181) \\
0.89(998.49 ; 4182)\end{array}$ & New & - & - & - & Filtered [78] & $\begin{array}{l}\text { Temperature and flow rate in } \\
2014\end{array}$ \\
\hline $\begin{array}{l}\text { StargardSzczecínski } \\
\text { GT-1 }\end{array}$ & $2001[38,72]$ & 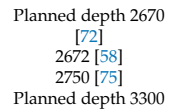 & $200[63]$ & $\begin{array}{l}\text { Lower Jurassic } \\
\text { [38,63] }\end{array}$ & $87[63]$ & $20.01(990.6 ; 4179)$ & New [37] & Production $[37,38]$ & $\begin{array}{l}\text { Vertical } \\
{[37,38]}\end{array}$ & $\begin{array}{c}\text { Steel/steel } \\
{[37,38]}\end{array}$ & $\begin{array}{l}\text { Widened, } \\
\text { filtered } \\
{[37,38]}\end{array}$ & $\begin{array}{l}\text { in } 2008 \text { the role of geothermal } \\
\text { boreholes was changed [37] }\end{array}$ \\
\hline $\begin{array}{c}\text { Stargard } \\
\text { Szczecinski GT-2k }\end{array}$ & $\begin{array}{l}2003[38,72] \\
2005[46]\end{array}$ & 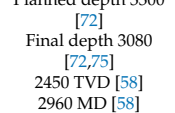 & - & Lower Jurassic [38] & - & & New [37] & Injection $[37,38]$ & $\begin{array}{l}\text { Directional } \\
{[37,38,72]}\end{array}$ & $\begin{array}{c}\text { Steel/steel } \\
{[37,38]}\end{array}$ & $\begin{array}{l}\text { Widened, bare } \\
\text { foot }[37,38]\end{array}$ & $\begin{array}{l}\text { In } 2000 \text { s the role of geothermal } \\
\text { boreholes was changed [37] } \\
\text { Depth of the start directional } 450 \\
\mathrm{~m} \text {, azimuth } 17^{\circ},{ }^{\circ} \text { maximum } \\
\text { angle } 39^{\circ}[72]\end{array}$ \\
\hline Stargard GT-3 & $2016[75]$ & $2665[75]$ & - & - & - & & - & Injection [75] & & - & Filtered876,6 & $\begin{array}{l}\text { The temperature of } \\
\text { sodiumm-chloridid warter was }\end{array}$ \\
\hline Swarzedz IGH-1 & $1982[$ [62] & 1306 [62] & 33.84 to 73.36 [62] & Lower Jurassic [62] & 36.6 to $42.2[62]$ & $1.44(998.7 ; 4183)$ & - & - & - & - & $\begin{array}{l}\text { to } 1300 \mathrm{~m}, \\
\text { with } \\
\text { perforation in } \\
138,06 \mathrm{~m}[62]\end{array}$ & $\begin{array}{l}\text { sodumum-hhoride water was } \\
39.6-42.2^{\circ} \mathrm{C} \text { and depended on } \\
\text { flow rate } 33.84 \text { do } 73.36 \mathrm{~m}^{3} / \mathrm{h} \\
{[62]}\end{array}$ \\
\hline $\begin{array}{l}\text { Szymoszkowa } \\
\text { GT-1 }\end{array}$ & $2006[75,76]$ & $1737[75,76]$ & $\begin{array}{l}70[50] \\
80[49]\end{array}$ & - & $27[49,50]$ & $2.20(999.3 ; 4187)$ & New $* * * *[75]$ & Production & Vertical & - & - & - \\
\hline $\begin{array}{l}\text { Tarnoworodgórne } \\
\text { GT-1 } \\
\text { Tomaszów } \\
\text { Mazowewecki GT-1 }\end{array}$ & $\begin{array}{l}2010[37,38] \\
2011[64,75]\end{array}$ & $\begin{array}{c}1200[63,64,75] \\
2090 \mathrm{~m}(+>-20 \%) \\
{[83]}\end{array}$ & $220[63,64]$ & $\begin{array}{c}\text { Lower Jurassic } \\
{[37,38,64]}\end{array}$ & $44[63,64]$ & $11.23(998.9 ; 4181)$ & $\begin{array}{l}\text { New } \\
\text { New }\end{array}$ & Production $[37,38]$ & $\begin{array}{c}\text { Vertical } \\
{[38]}\end{array}$ & $\begin{array}{c}\text { Steel/steel } \\
{[37,38]}\end{array}$ & $\begin{array}{l}\text { Widened, } \\
\text { filtered [37,38] }\end{array}$ & - \\
\hline $\begin{array}{l}\text { Torú GT-1 [38] } \\
\text { Torun TG-1 } \\
{[37,66,64,12]}\end{array}$ & $\begin{array}{c}2008[72] \\
2008 / 09[37,38,64]\end{array}$ & $\begin{array}{l}\text { Planned depth } 2970 \\
\text { Final } 22 \text { th } 2925 \\
\text { [ } 64,72]\end{array}$ & $350[63,64]$ & $\begin{array}{c}\text { Lower Jurassic } \\
\text { [77,38,64] } \\
\text { Lower Jurasic and } \\
\text { middle Triassic [63] }\end{array}$ & $64[63,64]$ & $25.87(995.1 ; 4178)$ & New [38] & Production $[37,38]$ & $\begin{array}{c}\text { Vertical } \\
{[38]}\end{array}$ & $\begin{array}{l}\text { Steel/fiberglass } \\
{[37,38]}\end{array}$ & $\begin{array}{l}\text { Widened, } \\
\text { filtered [37,38] }\end{array}$ & Flow rate $350 \mathrm{~m}^{3} / \mathrm{h}$ [63] \\
\hline $\begin{array}{l}\text { Torú GT-2 [38] } \\
\text { Torun TG-2 } \\
{[37,63,64,72]}\end{array}$ & $2009[37,38]$ & $2353[38]$ & - & $\begin{array}{c}\text { Lower Jurassic } \\
\quad[37,38]\end{array}$ & - & & New [38] & Injection $[37,38]$ & $\begin{array}{c}\text { Vertical } \\
{[38]}\end{array}$ & Fiberglassl/ - [37,38] & $\begin{array}{l}\text { Widened, } \\
\text { filtered [37,38] }\end{array}$ & - \\
\hline Trzesacz GT-1 & $2012[37,38,64]$ & $\begin{array}{r}1200[64] \\
1224.5[75]\end{array}$ & $180[64]$ & $\begin{array}{l}\text { Lower Jurassic } \\
{[37,38,63,64,75]}\end{array}$ & 27 [64] & $5.65(999.3 ; 4187)$ & New $* * * *$ & Production $[37,38]$ & $\begin{array}{c}\text { Vertical } \\
{[38]}\end{array}$ & $\begin{array}{c}\text { Steel } / \text { steel } \\
{[37,38]}\end{array}$ & $\begin{array}{l}\text { Widened, } \\
\text { filtered [37,38] }\end{array}$ & Flow rates: [66]: \\
\hline Uniejów IGH-1 & $1978[38,39,66]$ & $\begin{array}{c}2245[39] \\
2254[6,72]\end{array}$ & $\begin{array}{c}55[66] \\
65[66] \\
65.4[66] \\
(54.9)[66]\end{array}$ & $\begin{array}{c}\text { Lower Cretaceous } \\
{[39,57,66]}\end{array}$ & $68[66]$ & $4.32(994.4 ; 4178)$ & Archival & Injection $[37-39,66]$ & $\begin{array}{l}\text { Vertical } \\
{[37,38]}\end{array}$ & $\begin{array}{l}\text { Steel/- } \\
{[37,38]}\end{array}$ & $\begin{array}{c}\text { Perforated } \\
\text { pipes [37-39] }\end{array}$ & $\begin{array}{c}-65,4 \mathrm{~m}^{3} / \mathrm{h} \text { test production in } \\
1991 \\
65 \mathrm{~m}^{3} / \mathrm{h} \text { in } 1978 \\
55 \mathrm{~m}^{3} / \mathrm{h} \text { in } 1981 .\end{array}$ \\
\hline $\begin{array}{l}\text { Uniejów } \\
\text { PIG/AGH-1 }\end{array}$ & $1990 / 91[38,57,66]$ & $2065[39,66,72]$ & $\begin{array}{l}90.14[66] \\
(80.5)[66]\end{array}$ & $\begin{array}{c}\text { Lower Cretaceous } \\
{[38,39,57,66]}\end{array}$ & - & & $\begin{array}{l}\text { Archival [38] } \\
\text { New [37] }\end{array}$ & Injection $[37-39,66]$ & $\begin{array}{l}\text { Vertical } \\
{[37,38]}\end{array}$ & $\begin{array}{l}\text { Steel/- } \\
{[37,38]}\end{array}$ & $\begin{array}{c}\text { Perforated } \\
\text { pipes [37-39] }\end{array}$ & Flow rate $90.14 \mathrm{~m}^{3} / \mathrm{h}[66]$ \\
\hline
\end{tabular}


Table 1. Cont.

\begin{tabular}{|c|c|c|c|c|c|c|c|c|c|c|c|c|}
\hline Borehole Name & $\begin{array}{c}\text { Year of } \\
\text { Implementation }\end{array}$ & Depth $H, \mathrm{~m}$ & $\begin{array}{c}\text { Production } \\
(\text { Injection) Rate } \\
\dot{V}\left(\dot{V}_{i}\right), \mathrm{m}^{3} / \mathrm{h}\end{array}$ & Aquifer & $\begin{array}{l}\text { Geothermal Water } \\
\text { Temperature at the } \\
\text { Wellhead } T_{w h h}{ }^{\circ} \mathrm{C}\end{array}$ & 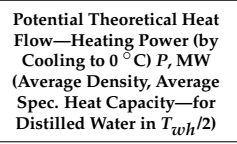 & Borehole Type & Borehole Purpose & $\begin{array}{c}\text { Spatial } \\
\text { Orientation }\end{array}$ & $\begin{array}{c}\text { Construction } \\
\text { Material: } \\
\text { Technical } \\
\text { Column/Pumping } \\
\text { Column } \\
\end{array}$ & $\begin{array}{c}\text { Borehole } \\
\text { Bottom }\end{array}$ & Comments \\
\hline $\begin{array}{c}\text { Uniejów } \\
\text { PIG/AGH-2 }\end{array}$ & $1990 / 91[38,66]$ & $\begin{array}{l}2031[66,72] \\
2042[39]\end{array}$ & $120[66]$ & $\begin{array}{c}\text { Lower Cretaceous } \\
{[38,39,57,66]}\end{array}$ & $\begin{array}{l}69.2[66] \\
62[63]\end{array}$ & $9.58(994.1 ; 4178)$ & $\begin{array}{l}\text { Archival [38] } \\
\text { New [37] }\end{array}$ & $\begin{array}{c}\text { Production } \\
{[38,39,66]}\end{array}$ & $\begin{array}{l}\text { Vertical } \\
{[37,38]}\end{array}$ & $\begin{array}{l}\text { Steel/steel } \\
{[37,38]}\end{array}$ & $\begin{array}{l}\text { Perforated } \\
\text { pipes [37-39] }\end{array}$ & $\begin{array}{l}\text { Flow rate } 120 \mathrm{~m}^{3} / \mathrm{h} \text { and } \\
\text { temperature } 69.2^{\circ} \mathrm{C} \text { in } 2005[66]\end{array}$ \\
\hline Ustroń IG-3 & & $1837.5[77]$ & & $6[77]$ & $\begin{array}{l}21[77] \\
32-\text { brine [52] }\end{array}$ & $0.15(999.77 ; 4191)$ & & & & & & \\
\hline Wrecza GT-1 & 2018 [75] & $1688[75]$ & 150 [75] & Kredadolna [75] & $\sim 40[75]$ & $6.96(998.3 ; 4182)$ & & & & & & \\
\hline Zakopane IG-1 & $\begin{array}{c}1961 / 63[76] \\
1963[58]\end{array}$ & $\begin{array}{c}3072.2[51,52] \\
3073[58] \\
3073.2[59,76]\end{array}$ & $50[49,50,59]$ & $\begin{array}{l}\text { Marl and limestones } \\
\text { (lower Jurassic) [59] }\end{array}$ & $\begin{array}{c}36[58] \\
37[49,50,59]\end{array}$ & $2.09(998.7 ; 4183)$ & Archival & - & Vertical & - & - & - \\
\hline Zakopane 2 & $\begin{array}{l}1973[58] \\
1975[76]\end{array}$ & $1113[59,76]$ & 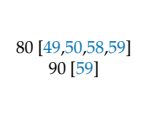 & $\begin{array}{c}\text { Namulite limestones } \\
\text { (middle Eocene) } \\
\text { and limestones and } \\
\text { dolomites (middle } \\
\text { Triassic) [59] } \\
\text { Namulite limestones }\end{array}$ & $\begin{array}{c}26[49,50,59] \\
26.6[58]\end{array}$ & $2.42(999.5 ; 4188)$ & Archival & - & - & - & - & $\begin{array}{l}\text { Flow rate } 90 \mathrm{~m}^{3} / \mathrm{h}[59] \text { and } 80 \\
\mathrm{~m}^{3} / \mathrm{h}[59] \text { in Table } 1 .\end{array}$ \\
\hline Zazadnia IG-1 & $1985 / 86[76]$ & $680[51,59]$ & $\begin{array}{l}25[49,50] \\
25.1[59]\end{array}$ & $\begin{array}{l}\text { (middle Eocene) } \\
\text { and limestones and } \\
\text { dolomites (middde } \\
\text { Triassic) [59] }\end{array}$ & $22[49,50,59]$ & $0.64(999.8 ; 4191)$ & Archival & - & - & - & - & - \\
\hline Total & & $12,8236.1$ & 6257,18 & & & 735.4 & & & & & & \\
\hline
\end{tabular}

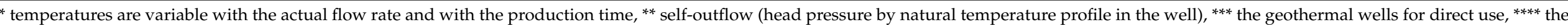
geothermal wells exploratory or research, ${ }^{* * * * *}$ the exploratory wells (but not for geothermal exploration), ${ }^{* * * * * *}$ the hydrogeological wells. 
Geothermal waters in Poland are most often used for recreational, heating and health purposes. Geothermal waters are used in heating plants in Stargard, Pyrzyce, Uniejów, Mszczonów, Poddębice and in Podhale [87]. Often, boreholes in Poland, as well as in other countries, are located in poorly urbanized areas. The distribution of geothermal installations in Poland is shown in Figure 1.

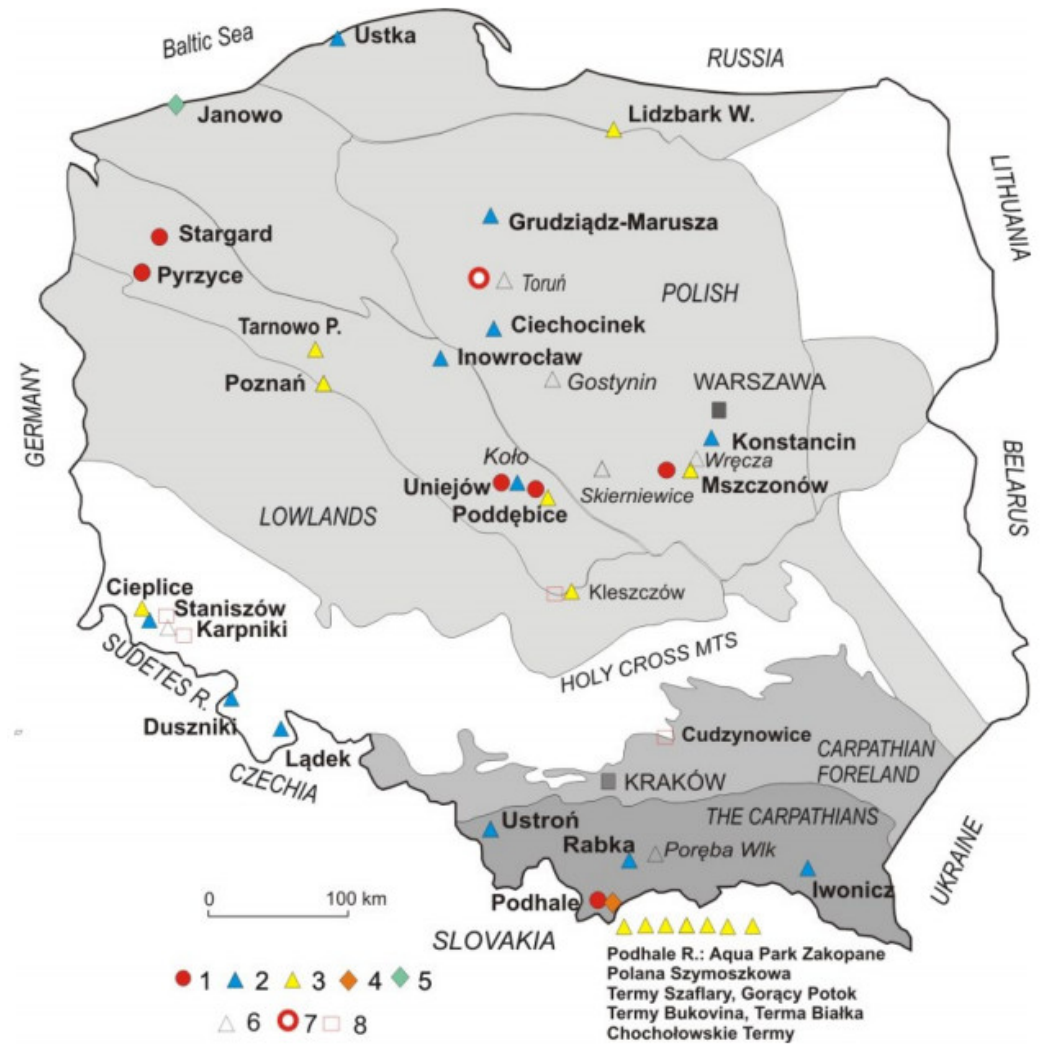

Figure 1. Geothermal uses in Poland in 2018: 1. District heating plants; 2. Health resorts; 3. Recreation centers; 4 . Wood drying; 5 . Fish farming; 6 . Some recreation centers in realization; 7. Heating system in realization; 8. Individual heating systems (individual heating systems in some recreation centers are not marked) [87].

Indicators of the ratio between the depth of geothermal boreholes and their power were proposed. The depth/efficiency ratio indicator was first proposed, according to the formula:

$$
N_{\dot{V}}=\frac{\sum \dot{V}}{\sum H}
$$

where $\dot{V}$ is the flowrate of possible geothermal water and $H$ is the depth of the borehole.

Qualification of boreholes to be included in the indicator is a debatable issue (1). The issue of selection is difficult because irrespective of the end use of the borehole (whether exploitation or injection), pumping tests are performed to determine the serviceability of the boreholes. Hence, the depth/efficiency ratio can be defined for different borehole configurations. Among the geothermal boreholes in Poland are: exploited production and injection boreholes, negative boreholes (boreholes planned and drilled in order to exploit geothermal water, in which the water was not found), boreholes not in operation. Efficiency is also debatable due to differences in values between multiple sources (cf. Table 1). Geothermal boreholes have approved resources of efficiency (productivity) and absorbency. Taking into account all geothermal boreholes for which data are available, the value of the indicator is $N_{\dot{V}}=0.04879 \mathrm{~m}^{3} / \mathrm{h} / \mathrm{m}$. The indicator takes into account all efficiency values, including injection boreholes (e.g., the Biały Dunajec PGP-2 has the approved productivity of $175 \mathrm{~m}^{3} / \mathrm{h}$ and an absorbance of $400 \mathrm{~m}^{3} / \mathrm{h}$, so only the first 
value was included in the calculation). Approved productivity means water resources determined by research conducted during pumping tests.

If the number of negative boreholes increases, the value of the indicator decreases. Considering, for example, the best geothermal borehole operating in Poland, its indicator equals $0.154 \mathrm{~m}^{3} / \mathrm{h} / \mathrm{m}$. Another issue is the depth of the boreholes, which previously served as reconnaissance boreholes. For example, the Bańska IG-1 well has a depth of $5261 \mathrm{~m}$, while the aquifer which is being exploited occurs at a much smaller depth. The difference between the depth of the geothermal borehole and the depth of the bottom of the aquifer varies for each borehole. The proposed indicator illustrates the "unitary" effort incurred for drilling for geothermal energy (from geothermal waters) in relation to the flow rate of water available for exploitation.

The second indicator proposed is the ratio of depth/theoretical power, according to the formula:

$$
N_{P}=\frac{\sum P}{\sum H}
$$

In which $P$ is the theoretical heating power, assuming water cooling from the well head temperature to $0{ }^{\circ} \mathrm{C}$ according to:

$$
P=\dot{V} \cdot \rho\left(T_{w h} / 2\right) \cdot c\left(T_{w h} / 2\right) \cdot T_{w h}
$$

where: $T_{w h} / 2$ is the average temperature of geothermal water.

The assumed cooling of water to $0{ }^{\circ} \mathrm{C}$ was adopted as a simple rule, easy to calculate and compare. By referencing the final temperature to $0{ }^{\circ} \mathrm{C}$, it is not necessary to know additional parameters, such as the average annual temperature of the atmospheric air, which is used to calculate the available geothermal resources (theoretical resources) under a given surface area [88]. Cooling water down to $0{ }^{\circ} \mathrm{C}$ is not feasible and technically impossible. Nevertheless, this value is quite universal and enables comparison of the energy resources (heating power) between wells. This is possible for both the high-temperature waters and the shallow water wells and natural hot springs. However, when providing such resources, it is good to also specify the water temperature, which, apart from the heating power, also indicates the quality of the obtained energy. Material parameters (density and specific heat) for calculating the amount of energy were assumed for the average temperature $T_{w h} / 2$, which is a simplification of the method and facilitates the comparison of geothermal wells.

Similar observations regarding depth and heating power relate to this indicator. Its value with the same assumptions as for the $N_{\dot{V}}$ equals $N_{P}=3523 \mathrm{~W} / \mathrm{m}$. Respectively, for the best Polish borehole (Bańska PGP-1), this indicator equals 16,589 W/m.

Figure 2 depicts the heads of selected geothermal boreholes in Poland.

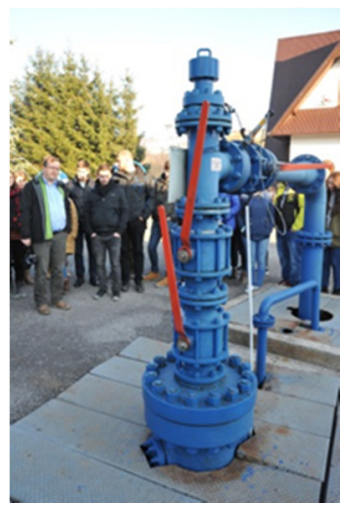

(a)

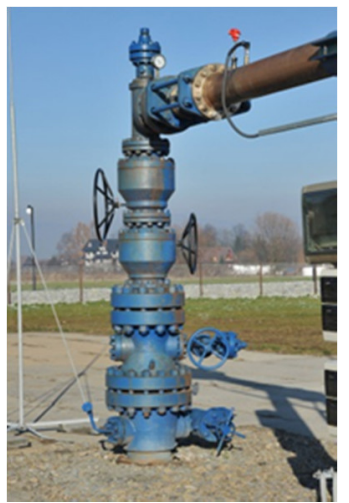

(b)

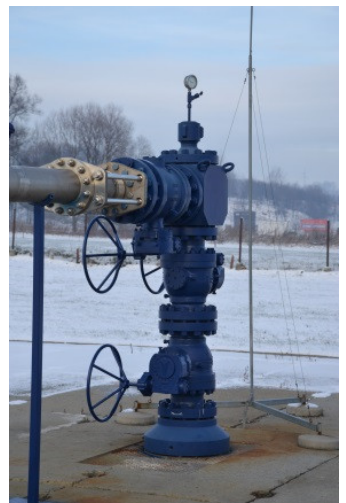

(c)

Figure 2. Cont. 


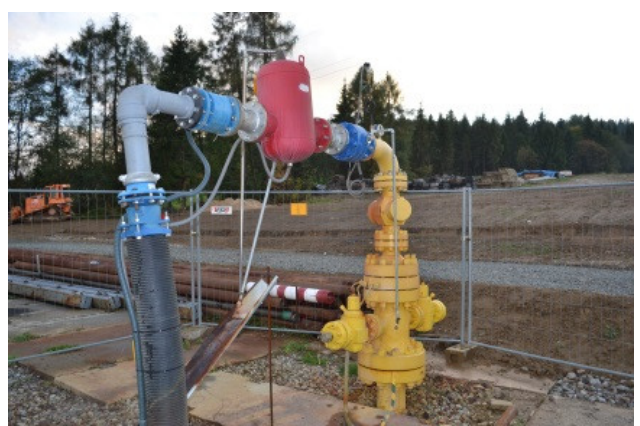

(d)

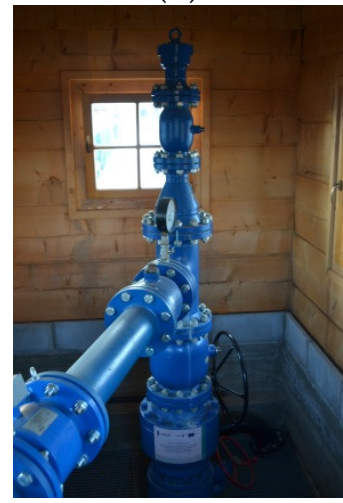

(f)

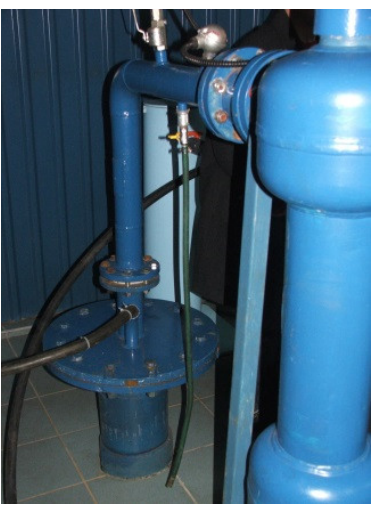

(h)

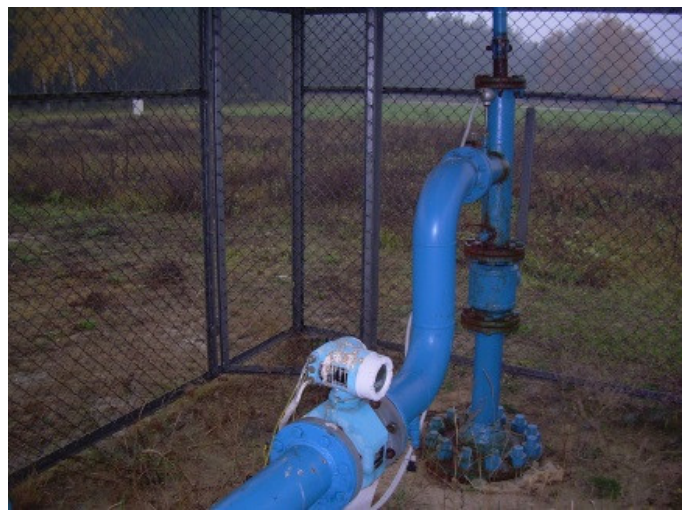

(k)

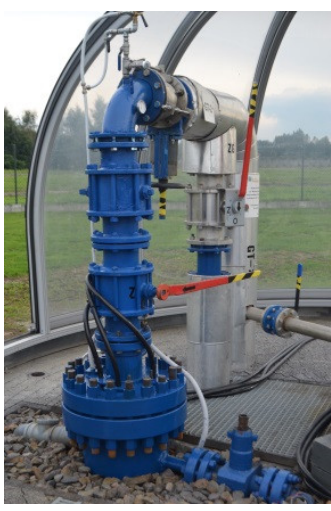

(i)

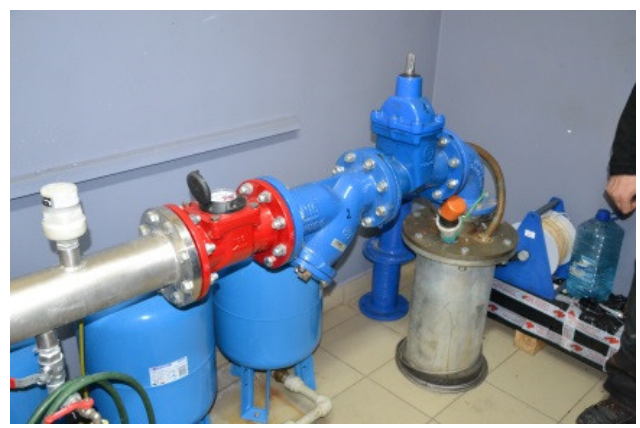

(e)

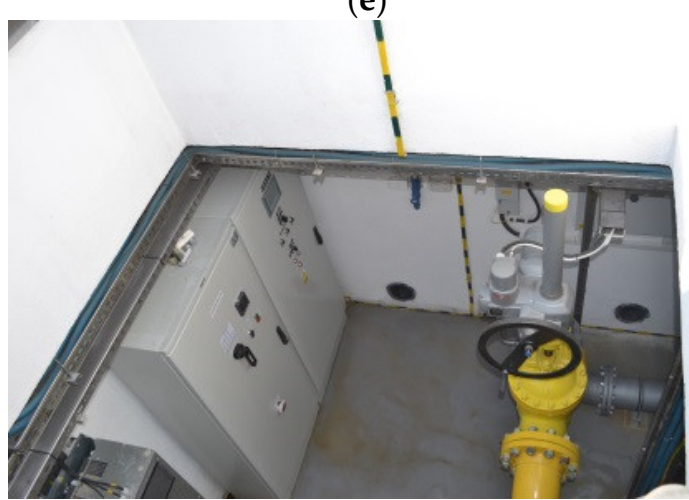

(g)

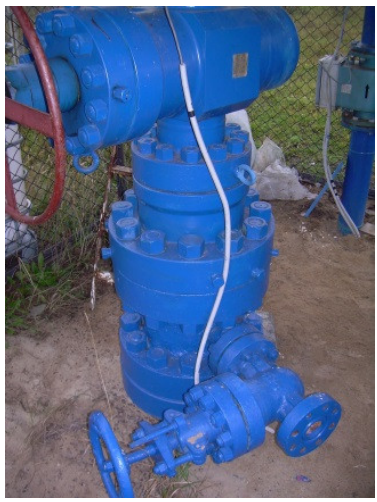

(j)

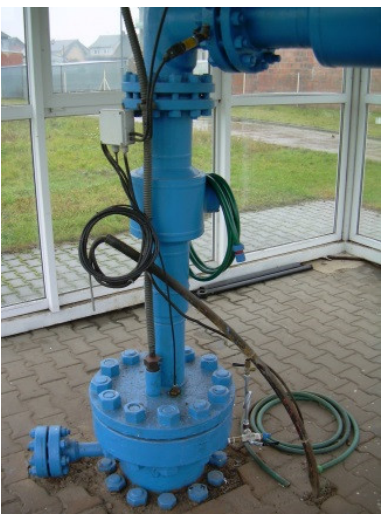

(1)

Figure 2. Well head of borehole: (a) Bańska IG-1, (b) Bańska PGP-1, (c) Bańska PGP-3, (d) BiałkaTatrzańska GT-1, (e) Bukowina Tatrzańska PIG/PNiG-1, (f) Chochołów PIG-1, (g) Kleszczów GT-1, (h) Mszczonów IG-1, (i) Poddębice GT-2, (j) Uniejów PIG/AGH-1, (k) Uniejów IG-1, (1) Uniejów PIG/AGH-2. 


\section{Borehole Heat Exchangers}

The advantages of the collection of the Earth's heat with borehole heat exchangers include the lack of risk connected with prospecting drilling, very high durability (lifetime) and minimal impact on the environment [89]. This chapter presents the materials most commonly used in borehole heat exchangers, as well as the innovative constructions of BHE at AGH UST in Krakow.

\subsection{Materials Used in Geothermal BHEs}

Borehole heat exchangers have basic construction [89]:

- Single U-pipe,

- Double U-pipe,

- Multi U-pipe,

- Coaxial exchanger.

Types of plastics are most often used as the material for borehole heat exchangers. Their main advantage is the lack of corrosion on contact with water. The most commonly used materials are [88]:

- Chlorinated polyvinyl chloride,

- Polybutylene,

- Polyethylene,

- Polypropylene.

Table 2 summarizes the basic properties of materials used in borehole heat exchangers.

Table 2. List of basic properties of materials used in borehole heat exchangers.

\begin{tabular}{|c|c|c|c|c|c|}
\hline Material & $\begin{array}{l}\text { Density, } \rho_{p}, \\
\mathrm{~kg} / \mathrm{m}^{3}\end{array}$ & $\begin{array}{l}\text { Thermal Expansion } \\
\text { Coefficient, } \Delta l, 1 / \mathrm{K}\end{array}$ & $\begin{array}{l}\text { Thermal Conductivity, } \\
\qquad \lambda_{p}, \mathrm{~W} /(\mathrm{mK})\end{array}$ & $\begin{array}{l}\text { Specific Heat, } c_{p}, \\
\mathrm{~kJ} /(\mathrm{kgK})\end{array}$ & $\begin{array}{c}\text { Young's } \\
\text { Modulus, } E, \\
\text { GPa }\end{array}$ \\
\hline $\begin{array}{l}\text { chlorinated } \\
\text { polyvinyl chloride }\end{array}$ & 960 & $8 \times 10^{-5}$ & 0.41 & 1.84 & 2.5 \\
\hline polybutylene & 939 & - & 0.22 & - & 0.34 \\
\hline polyethylene & $940-970$ & $10^{-5}$ & 0.42 & 1.15 & 0.2 \\
\hline polypropylene & 909 & $1.5 \cdot \times 10^{-5}$ & 0.22 & 1.7 & $1.5-2.0$ \\
\hline
\end{tabular}

The most appropriate materials, according to the authors [89,90], for the production of borehole heat exchangers' tubes are polypropylene and polyethylene.

For the grouting of borehole heat exchangers, most commonly used are mixtures with trade names Calidutherm by Terra Calidus, Hekoterm by Hekobentonity, RaugeoTherm by Rehau, StüwaTherm by Stüwa and Thermocem Plus by Górażdże. Hekoterm is also known under brands such as TermorotaS or MuoviTerm [91]. The key parameter that should be specified for grout is increased thermal conductivity.

Grout with increased thermal conductivity is a constantly evolving research topic. The use of graphite as an additive to grout was considered by many authors, such as Lee et al., Sliwa et al., Delaleux et al., Sapińska-Sliwa [92-97].

Studies of the heat flow through BHE can be found in the literature. One of the methods is the use of the laboratory model described by Shirazi and Bernier to simulate the well conditions. Moreover, they compared the numerical and experimental results [98]. In classic methods of analyzing a ground heat exchanger, the heat capacity of boreholes is often neglected. Analytical solutions to this issue are presented in the works of Lemarche $[99,100]$. Taking into account the influence of the thermal capacity of the borehole on the thermal response of the ground was also described by Nian and Cheng [101].

\subsection{Borehole Heat Exchangers at AGH UST in Krakow}

Borehole heat exchangers are the subject of research both in Poland and around the world. The Laboratory of Geoenergetics at the Faculty of Drilling, Oil and Gas at AGH UST 
in Krakow has two research stations equipped with borehole heat exchangers of various constructions (Table 3). The first installation includes five BHEs made in January and February 2008 [102]. The second geothermal field station was constructed in the summer of 2017 on the occasion of the 10th anniversary of the Geoenergetics Laboratory. This installation consists of 14 borehole heat exchangers made using the rotary method [10].

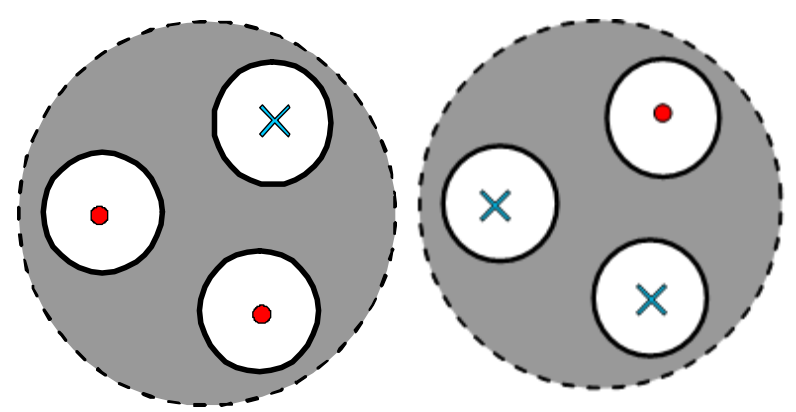

Figure 3. Innovative system [103]; with two options of circulating heat carrier (LG-11b in Table 3).

Table 3. Constructions of borehole heat exchangers (Laboratory of Geoenergetics at the Faculty of Drilling, Oil and Gas at AGH UST in Krakow) [10,103].

\begin{tabular}{|c|c|c|c|c|c|}
\hline $\begin{array}{l}\text { Name of } \\
\text { Borehole Heat } \\
\text { Exchanger }\end{array}$ & $\begin{array}{l}\text { Constructions of } \\
\text { Borehole Heat } \\
\text { Exchanger }\end{array}$ & Type of Grout & $\begin{array}{l}\text { Outer Diameter of Inner } \\
\quad \text { Pipes, } D_{z}\left(d_{z}\right), m m\end{array}$ & $\begin{array}{l}\text { Wall thickness of } \\
\text { Pipes, b, mm }\end{array}$ & $\begin{array}{l}\text { Type of Pipes } \\
\text { Material }\end{array}$ \\
\hline LG-1a & coaxial & cement slurry & \multicolumn{2}{|c|}{$\begin{array}{l}\text { Casing (outside) pipe } D_{z}=90 \mathrm{~mm} \text { and } b=5.4 \\
\mathrm{~mm} \text {; inner pipe } d_{z}=40 \mathrm{~mm} \text { and } b=2.4 \mathrm{~mm}\end{array}$} & $\begin{array}{l}\text { PE, internally } \\
\text { smooth pipe } \\
\text { (laminar collector) }\end{array}$ \\
\hline LG-2a & single U-pipe & cement slurry & 40 & 2.4 & $\begin{array}{l}\text { PE, internally } \\
\text { smooth pipe } \\
\text { (laminar collector) }\end{array}$ \\
\hline LG-3a & single U-pipe & $\begin{array}{l}\text { cement slurry with } \\
\text { increased value of } \\
\text { thermal conductivity } \\
\text { (ThermoCem) }\end{array}$ & 40 & 2.4 & $\begin{array}{c}\text { PE, internally } \\
\text { smooth pipe } \\
\text { (laminar collector) }\end{array}$ \\
\hline LG-4a & single U-pipe & $\begin{array}{l}\text { gravel, size } 8-16 \mathrm{~mm} \\
\text { and two clay plugs } \\
\text { (Compactonit) }\end{array}$ & 40 & 2.4 & $\begin{array}{l}\text { PE, internally } \\
\text { smooth pipe } \\
\text { (laminar collector) }\end{array}$ \\
\hline LG-5a & double U-pipe & cement slurry & 32 & 2.4 & $\begin{array}{l}\text { PE, internally } \\
\text { smooth pipe } \\
\text { (laminar collector) }\end{array}$ \\
\hline LG-1b & double U-pipe & $\begin{array}{l}\text { cement slurry with } \\
\text { increased value of } \\
\text { thermal conductivity } \\
\text { (TermorotaS) }\end{array}$ & 32 & 3.0 & $\begin{array}{c}\text { PE, internally } \\
\text { smooth pipe } \\
\text { (laminar collector) }\end{array}$ \\
\hline LG-2b & single U-pipe & $\begin{array}{l}\text { cement slurry with } \\
\text { increased value of } \\
\text { thermal conductivity } \\
\text { (TermorotaS) }\end{array}$ & 32 & 3.0 & $\begin{array}{l}\mathrm{PE}, \text { internally } \\
\text { rough pipe } \\
\text { (turbocollector) }\end{array}$ \\
\hline LG-3b & double U-pipe & $\begin{array}{l}\text { cement slurry with } \\
\text { increased value of } \\
\text { thermal conductivity } \\
\text { (TermorotaS) }\end{array}$ & 40 & 3.0 & $\begin{array}{l}\mathrm{PE}, \text { internally } \\
\text { rough pipe } \\
\text { (turbocollector) }\end{array}$ \\
\hline LG-4b & double U-pipe & $\begin{array}{l}\text { cement slurry with } \\
\text { increased value of } \\
\text { thermal conductivity } \\
\text { (TermorotaS) }\end{array}$ & 40 & 3.0 & $\begin{array}{l}\mathrm{PE} \text {, internally } \\
\text { rough pipe } \\
\text { (turbocollector) }\end{array}$ \\
\hline LG-5b & single U-pipe & $\begin{array}{l}\text { cement slurry with } \\
\text { increased value of } \\
\text { thermal conductivity } \\
\text { (TermorotaS) }\end{array}$ & 40 & 3.0 & $\begin{array}{c}\text { PE, internally } \\
\text { smooth pipe } \\
\text { (laminar collector) }\end{array}$ \\
\hline LG-6b & single U-pipe & $\begin{array}{l}\text { cement slurry with } \\
\text { increased value of } \\
\text { thermal conductivity } \\
\text { (TermorotaS) }\end{array}$ & 40 & 3.0 & $\begin{array}{l}\mathrm{PE}, \text { internally } \\
\text { rough pipe } \\
\text { (turbocollector) }\end{array}$ \\
\hline
\end{tabular}


Table 3. Cont.

\begin{tabular}{|c|c|c|c|c|c|}
\hline $\begin{array}{l}\text { Name of } \\
\text { Borehole Heat } \\
\text { Exchanger }\end{array}$ & $\begin{array}{l}\text { Constructions of } \\
\text { Borehole Heat } \\
\text { Exchanger }\end{array}$ & Type of Grout & $\begin{array}{l}\text { Outer Diameter of Inner } \\
\text { Pipes, } D_{z}\left(d_{z}\right), m m\end{array}$ & $\begin{array}{l}\text { Wall thickness of } \\
\text { Pipes, b, mm }\end{array}$ & $\begin{array}{l}\text { Type of Pipes } \\
\text { Material }\end{array}$ \\
\hline LG-7b & single U-pipe & $\begin{array}{l}\text { cement slurry with } \\
\text { increased value of } \\
\text { thermal conductivity } \\
\text { (TermorotaS) }\end{array}$ & 45 & 3.0 & $\begin{array}{l}\mathrm{PE} \text {, internally } \\
\text { rough pipe } \\
\text { (turbocollector) }\end{array}$ \\
\hline LG-8b & single U-pipe & $\begin{array}{l}\text { cement slurry with } \\
\text { increased value of } \\
\text { thermal conductivity } \\
\text { (TermorotaS) }\end{array}$ & 32 & 3.0 & $\begin{array}{l}\text { PE, internally } \\
\text { rough pipe } \\
\text { (turbocollector) }\end{array}$ \\
\hline LG-9b & single U-pipe & $\begin{array}{l}\text { cement slurry with } \\
\text { increased value of } \\
\text { thermal conductivity } \\
\text { (TermorotaS) in } \\
\text { interval } 0-20 \mathrm{~m}\end{array}$ & 32 & 2.9 & $\begin{array}{l}\text { PE, internally } \\
\text { rough pipe } \\
\text { (turbocollector) }\end{array}$ \\
\hline LG-10b & $\begin{array}{c}\text { innovative } \\
\text { system (Figure 3) }\end{array}$ & $\begin{array}{l}\text { cement slurry with } \\
\text { increased value of } \\
\text { thermal conductivity } \\
\text { (TermorotaS) }\end{array}$ & 40 & 3.0 & $\begin{array}{l}\text { PE, internally } \\
\text { rough pipe } \\
\text { (turbocollector) }\end{array}$ \\
\hline LG-11b & $\begin{array}{c}\text { innovative } \\
\text { system (Figure 3) }\end{array}$ & typical mortar & 40 & 3.0 & $\begin{array}{l}\text { PE, internally } \\
\text { rough pipe } \\
\text { (turbocollector) }\end{array}$ \\
\hline LG-12b & single U-pipe & cement slurry & 32 & 2.9 & $\begin{array}{l}\text { PE, internally } \\
\text { rough pipe } \\
\text { (turbocollector) }\end{array}$ \\
\hline LG-13b & double U-pipe & $\begin{array}{l}\text { cement slurry with } \\
\text { increased value of } \\
\text { thermal conductivity } \\
\text { (TermorotaS) }\end{array}$ & \multicolumn{3}{|c|}{$\begin{array}{c}\text { First U-pipe } \\
-\mathrm{d}_{\mathrm{z}}=32 \mathrm{~mm} \text {, turbocollector, } \mathrm{b}=3.0 \mathrm{~mm} \\
\mathrm{~d}_{\mathrm{z}}=32 \mathrm{~mm} \text {, turbocollector, } \mathrm{b}=3.0 \mathrm{~mm} \\
\text { Second U-pipe: } \\
\mathrm{d}_{\mathrm{z}}=40 \mathrm{~mm} \text {, laminar collector, } \mathrm{b}=3.0 \mathrm{~mm} \\
\mathrm{~d}_{\mathrm{z}}=40 \mathrm{~mm} \text {, laminar collector, } \mathrm{b}=3.0 \mathrm{~mm}\end{array}$} \\
\hline LG-14b & single U-pipe & $\begin{array}{l}\text { cement slurry with } \\
\text { increased value of } \\
\text { thermal conductivity } \\
\text { (TermorotaS) with } \\
\text { graphite }\end{array}$ & 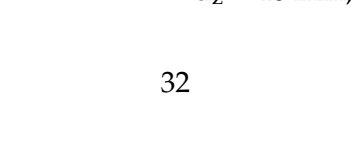 & (5) & $\begin{array}{l}\text { PE, internally } \\
\text { rough pipe } \\
\text { (turbocollector) }\end{array}$ \\
\hline
\end{tabular}

For borehole heat exchangers, there is no reason for the $N_{\dot{V}}$ indicator. Similar to the geothermal boreholes, one can be tempted to determine the value of the indicator $\mathrm{N}_{\mathrm{p}}$. BHEs work with varying loads. The way to determine BHE's energy efficiency is to perform a Thermal Response Test [19]. TRT allows for the determination of the effective thermal conductivity. Thermal conductivity can also be determined by analyzing the undisturbed temperature profile in the borehole [104]. The natural temperature profile can be examined with the NIMO-T probe. Many of the temperature-depth plots show some correctness. In general, the temperature in the near-surface layers varies depending on the season. In some profiles, a decrease in the rocks' temperature to a great depth can be observed. High heat penetration from the surface is related to the city infrastructure, not only solar radiation. The main factor influencing the soil environment is the extensive urban infrastructure, e.g., the presence of pipelines (water supply, sewage, heat pipelines), asphalt, and black road surfaces, which cause the absorption of additional amounts of solar heat from the surface. The foundations of heated buildings also cause heat transfer to the subsurface rocks. In cities, the depth of periodic heat penetration is usually greater than in non-urban areas [103]. The easiest, but least accurate approach is to determine the thermal conductivity of the ground, based on lithology and literature data $[89,105]$.

Since the proper operation of the plate of geothermal systems is planned for decades, an important issue is to show the long-term behavior of exchangers. The thermal response of slender geothermal boreholes to subannual harmonic excitations is described by Hermanns and Ibanez [106]. Simple empirical formulas correlate the effective thermal conductivity with the unitary heating power of BHEs [107]:

$$
q_{1}=20 \cdot \lambda_{e f f}
$$


and

$$
q_{2}=13 \cdot \lambda_{e f f}+10
$$

However, it is not possible to determine the global (national) value of the indicator $N_{P}$ for BHEs, due to the lack of data on the number and depth of BHEs made in Poland, and the small percentage of TRTs conducted. The collection of data on the created heat pump installations with borehole exchangers is not required, hence it is impossible to identify and collect all information about the created systems. Moreover, there is no legal regulation in Poland regarding the obligation to perform TRT, therefore these tests are performed sporadically and only on large investments. Specification of the individual values for local geology and a given depth is very much possible. For example, for boreholes located in the Laboratory of Geoenergetics AGH UST, the thermal conductivity value of rocks based on literature data (for BHEs LG1a-LG5a) equals $2.039 \mathrm{~W} /(\mathrm{mK})$ [89]. The $N_{P}$ value as the mean of $q_{1}$ and $q_{2}$ from Equations (4) and (5) is $38.64 \mathrm{~W} / \mathrm{m}$. It is many times less than the value $N_{P}=3523 \mathrm{~W} / \mathrm{m}$ for boreholes that exploit geothermal water. As opposed to geothermal waters, which do not occur everywhere, BHEs can be created regardless of geological conditions, and using increasingly affordable methods [108].

TRT tests are currently underway for BHEs belonging to the Laboratory of Geoenergetics AGH UST. Their results will determine the impact of various design parameters on the effective heat conductivity, borehole thermal resistance $[109,110]$ and operational parameters [101].

A not very common variant of BHE is the deep borehole heat exchanger (DBHE). Until now, they have been studied and used only in the USA, Germany, Switzerland and Poland [111], and most recently also in China.

In 1999, one of the world's deepest borehole heat exchangers $(2780 \mathrm{~m})$ was made in Poland. It has been used for research purposes only. Due to the use of an inadequate centric tube column, satisfactory results were not obtained [112]. A key structural element in DBHEs is the internal insulating pipe column [99]. The longest-running DBHE is now an exchanger in Prenzlau (Germany), which has been in operation since 1992 [113].

Deep borehole heat exchangers are not currently used for economic reasons. Such installations are unprofitable at current heat prices. They are, however, a forward-looking source of heat when one considers ${ }^{\mathrm{TM}}$ hundreds of millions of drilled oil wells around the world.

Research on systems based on exploited and negative oil and gas wells should be carried out, as such installations can be used for heating in the future. Areas with old, decommissioned, or intended-for-decommissioning wells may then become more valuable due to the availability of an independent heat source. Only the energy which drives the heat pump (not always necessary-depending on the borehole depth) and the circulation of the heat carrier in the exchanger would have to be provided.

For instance, in the years 2016-2017, more than 120,000 oil and gas exploration and reconnaissance boreholes with a total depth of over 337.5 million meters [114] were made worldwide. With a careful approach, they could exchange heat with a rock mass reaching the heating power of more than $8 \mathrm{GW}$. It seems prudent to consider drilling new boreholes with potential future use in the form of deep borehole heat exchangers. For example, appropriately modified sealing slurry (with adjustable thermal conductivity) could be used.

Table 4 shows the present deep geothermal district heating plants and other uses for heating. Table 5 summarizes the data on geothermal heat pumps in Poland.

Table 4. Present deep geothermal district heating plants and other uses for heating in 2018 [87].

\begin{tabular}{cccccccc}
\hline Geothermal District Heating & \multicolumn{2}{c}{$\begin{array}{c}\text { Geothermal Heat in } \\
\text { Agriculture and Industry }\end{array}$} & $\begin{array}{c}\text { Geothermal Heat for } \\
\text { Buildings }\end{array}$ & $\begin{array}{c}\text { Geothermal Heat in } \\
\text { Balneology and Other }\end{array}$ \\
\hline Capacity, & Production, & Capacity, & Production, & Capacity, & Production, & Capacity, & Production, \\
MW & GWh/y & MW & GWh/y & MW & GWh/y & MW & GWh/y \\
74.6 & 250.4 & 4 & 6 & $>10$ & $>25$ & $>12$ & $>35$ \\
\hline
\end{tabular}


Table 5. Geothermal heat pumps in Poland [87].

\begin{tabular}{cccc}
\hline Description & Number & Capacity, MW & Production, GWh/y \\
\hline In operation end of 2017 & 56,000 & 650 & 861 \\
Projected total by 2020 & 74,000 & 860 & 1140 \\
\hline
\end{tabular}

\section{Conclusions}

Renewable energy sources are increasingly used around the world. These include geothermal energy, which is exploited by geothermal boreholes and borehole heat exchangers. The authors came to the following conclusions:

1. In Polish geothermal wells, casing pipes are usually made of steel.

2. The first geothermal boreholes in Poland were vertical and made of steel pipes. Currently, directional boreholes and fiberglass pipes are present, which reflects the development of techniques and technology.

3. Borehole heat exchangers (BHEs) are increasingly used. The advantages of collecting Earth's heat with borehole heat exchangers include no risk connected with prospecting drilling, very high durability (lifetime) and minimal impact on the environment.

4. There are two installations of borehole heat exchangers on the site of the AGH UST in Krakow. The first consists of 5, while the second of 14 borehole heat exchangers with an innovative system. It is the largest installation of BHEs with different designs in the world.

5. Comparative indicators for drilling efficiency for geothermal boreholes in Poland have been proposed. These indicators can be determined in any country where exploitation boreholes for geothermal heat are made. This applies both to geothermal boreholes (i.e., those related to geothermal water) as well as borehole heat exchangers (i.e., openings which obtain the Earth's heat without hydraulic contact with the rock mass).

6. Two indicators for the effectiveness of drilling were proposed for geothermal boreholes. The first is the "unitary" cost of obtaining geothermal water's one unit of efficiency $N_{\dot{V}^{\prime}}$ the second is the indicator of theoretical power per one meter of existing and created boreholes $N_{P}$. For geothermal boreholes in Poland, $N_{\dot{V}}=0.04879$ $\mathrm{m}^{3} / \mathrm{h} / \mathrm{m}$ and $N_{P}=3523 \mathrm{~W} / \mathrm{m}$. For borehole heat exchangers, it is impossible to determine the values of these indicators for the entire country due to the reasons described in the article. Local (individual) $N_{P}$ values can be determined based on the rock's heat conductivity. For BHEs located in AGH UST, $N_{P}$ equals $38.64 \mathrm{~W} / \mathrm{m}$. The difference is also reflected in the cost. The unitary cost of drilling the BHE is many times less than the unitary cost of drilling a geothermal borehole.

7. Boreholes drilled in the past (including those already decommissioned) and those which will be drilled in the future can be adapted for geothermal purposes. If there is no aquifer present, they can be used for deep borehole heat exchangers. For this purpose, they can currently be designed taking into consideration future geothermal applications.

Author Contributions: Conceptualization, T.S. and A.S.-Ś; methodology, T.S.; software, A.S.; validation, A.G.; formal analysis, A.G.; investigation, T.K.; resources, A.S.; data curation, A.S.; writingoriginal draft preparation, T.K.; writing-review and editing, T.S.; visualization, T.S.; supervision, T.S.; project administration, A.S.-Ś.; funding acquisition, T.S. All authors have read and agreed to the published version of the manuscript.

Funding: The research leading to these results has received funding from the Norway Grants 20142021 via the National Centre for Research and Development in Warsaw. Research project supported also by program "Excellence initiative-research university" for the AGH University of Science and Technology.

Institutional Review Board Statement: Not applicable. 
Informed Consent Statement: Not applicable.

Data Availability Statement: Not applicable.

Conflicts of Interest: The authors declare no conflict of interest.

\section{Nomenclature}

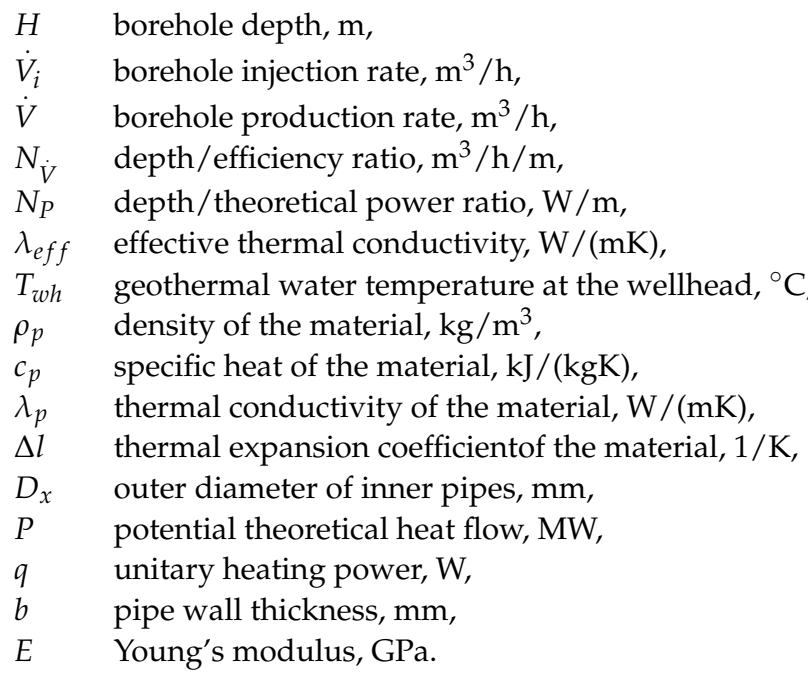

\section{References}

1. Sapińska-Śliwa, A.; Wiglusz, T.; Kruszewski, M.; Sliwa, T.; Kowalski, T. Wiercenia Geotermalne: Doświadczenia Techniczne i Technologiczne (Geothermal Drilling: Techniques and Side Aspects); Laboratory of Geoenergetics Book Series; Drilling, Oil and Gas Foundation: Krakow, Poland, 2017; Volume 3. (In Polish)

2. Zhou, Z.; Jin, Y.; Zeng, Y.; Youn, D. Experimental Study of Hydraulic Fracturing in Enhanced Geothermal System. In Proceedings of the ARMA-2018-148, American Rock Mechanics Association, 52nd US Rock Mechanics/Geomechanics Symposium, Seattle, WA, USA, 17-20 June 2018.

3. Olasolo, P.; Juarez, M.C.; Morales, M.P.; D'Amico, S.; Liarte, I.A. Enhanced geothermal systems (EGS): A review. Renew. Sustain. Energy Rev. 2016, 56, 133-144. [CrossRef]

4. Lu, S.M. A global review of enhanced geothermal system (EGS). Renew. Sustain. Energy Rev. 2018, 81, 2902-2921. [CrossRef]

5. Ng, K.W.; Poudel, R.; Kyle, W.; Tan, G.; Podgorney, R. A Laboratory Experimental Study of Enhanced Geothermal Systems. In Proceedings of the ARMA-2017-0415, American Rock Mechanics Association, 51st US Rock Mechanics/Geomechanics Symposium, San Francisco, CA, USA, 25-28 June 2017.

6. Yoo, H.; Park, S.; Xie, L.; Min, K.B.; Rutqvist, J.; Rinaldi, A.P. Numerical Modeling of Coupled Hydromechanical Behavior of Fractured Geothermal Reservoir at Pohang Enhanced Geothermal System (EGS) Site. In Proceedings of the ISRM-YSS-2017-089, International Society for Rock Mechanics and Rock Engineering, 4th ISRM Young Scholars Symposium on Rock Mechanics, Jeju, Korea, 10-13 May 2017.

7. Tang, M.; Li, H.; Tang, C. Study on Deep Underground Geometrical Model for Enhanced Geothermal System Based on Excavation. In Proceedings of the ISRM-ARMS10-2018-034, International Society for Rock Mechanics and Rock Engineering, ISRM International Symposium-10th Asian Rock Mechanics Symposium, Singapore, 29 October-3 November 2018.

8. Han, S.; Cheng, Y.; Gao, Q.; Yan, C.; Wie, J.; Zhang, J. Simulation Study on Heat Extraction in Enhanced Geothermal Reservoirs with Random Fracture Distribution. In Proceedings of the ARMA-2019-1857, American Rock Mechanics Association, 53rd US Rock Mechanics/Geomechanics Symposium, New York, NY, USA, 23-26 June 2019.

9. Florides, G.; Christodoulides, P.; Theofanous, E.; Lazari, L.; Messeritis, V. Modeling of Geothermal Heat Exchangers. In Proceedings of the ISOPE-I-13-168, International Society of Offshore and Polar Engineers, The 23rd International Offshore and Polar Engineering Conference, Anchorage, AK, USA, 30 June-5 July 2013.

10. Sliwa, T.; Gonet, A.; Złotkowski, A.; Sapińska-Śliwa, A.; Bieda, A.; Kowalski, T. Geotermia na Wydziale Wiertnictwa, Nafty i Gazu Akademii Górniczo-Hutniczej w Krakowie. Laboratorium Geoenergetyki: 10 lat działalności (Laboratory of Geoenergetics: 10 years of activity: Geothermics at Drilling, Oil and Gas Faculty of AGH University of Science and Technology in Krakow); Laboratory of Geoenergetics Book Series; Drilling, Oil and Gas Foundation: Krakow, Poland, 2017; Volume 4. (In Polish)

11. Aresti, L.; Christodoulides, P.; Florides, G. A review of the design aspect of ground heat exchangrs. Renew. Sustain. Energy Rev. 2018, 92, 757-773. [CrossRef]

12. Soni, S.K.; Pandey, M.; Bartaria, V.N. Hybrid ground coupled heat exchanger systems for space heating/cooling applications: A review. Renew. Sustain. Energy Rev. 2016, 60, 724-738. [CrossRef] 
13. Bayer, P.; Attard, G.; Blum, P.; Menberg, K. The geothermal potential of cities. Renew. Sustain. Energy Rev. 2019, 106, 17-30. [CrossRef]

14. Sliwa, T.; Gonet, A. Theoretical model of borehole heat exchanger. J. Energy Resour. Technol. 2005, 127, 142-148. [CrossRef]

15. Jaszczur, M.; Polepszyc, I.; Sapińska-Śliwa, A. Numerical analysis of the boundary conditions model impact on the estimation of heat resources in the ground. Pol. J. Environ. Stud. 2015, 24, 60-66.

16. Cui, Y.; Zhu, J.; Twaha, S.; Riffat, S. A comprehensive review on 2D and 3D models of vertical ground heat exchangers. Renew. Sustain. Energy Rev. 2018, 94, 84-114. [CrossRef]

17. Spitler, J.D.; Gehlin, S.E.A. Thermal response testing for ground source heat pump systems-An historical review. Renew. Sustain. Energy Rev. 2015, 50, 1125-1137. [CrossRef]

18. Zarrella, A.; Emmi, G.; Graci, S.; De Carli, M.; Cultrea, M.; Dalla Santa, G.; Galgaro, A.; Bertermann, D.; Muller, J.; Pckele, L.; et al. Thermal Response Testing Results of Different Types of Borehole Heat Exchangers: An Analysis and Comparison of Interpretation Methods. Energies 2017, 10, 801. [CrossRef]

19. Sapińska-Śliwa, A.; Rosen, M.A.; Gonet, A.; Kowalczyk, J.; Sliwa, T. A new method based on thermal response tests for determining effective thermal conductivity and borehole resistivity for borehole heat exchangers. Energies 2019, $12,1072$. [CrossRef]

20. Wilke, S.; Menberg, K.; Steger, H.; Blum, P. Advanced thermal response tests: A review. Renew. Sustain. Energy Rev. 2020, 119, 109575. [CrossRef]

21. Zhang, X.; Zhang, T.; Li, B.; Jiang, Y. Comparison of Four Methods for Borehole Heat Exchanger Sizing Subject to Thermal Response Test Parameter Estimation. Energies 2019, 12, 4067. [CrossRef]

22. Liu, Y.; Hou, J.; Zhao, H.; Liu, X.; Xia, Z. Numerical simulation of simultaneous exploitation of geothermal energy and natural gas hydrates by water injection into a geothermal heat exchange well. Renew. Sustain. Energy Rev. 2019, 109, 467-481. [CrossRef]

23. Dai, C.; Li, J.; Shi, Y.; Zeng, L.; Lei, H. An experiment on heat extraction from a deep geothermal well using a downhole coaxial open loop design. Appl. Energy 2019, 252, 113447. [CrossRef]

24. Song, X.; Shi, Y.; Li, G.; Yang, R.; Wang, G.; Zheng, R.; Li, J.; Lyu, Z. Numerical simulation of heat extraction performance in enhanced geothermal system with multilateral wells. Appl. Energy 2018, 218, 325-337. [CrossRef]

25. Nian, Y.; Cheng, W. Insights into geothermal utilization of abandoned oil and gas wells. Renew. Sustain. Energy Rev. 2018, 87, 44-60. [CrossRef]

26. Menéndez, J.; Ordóñez, A.; Álvarez, R.; Loredo, J. Energy from closed mines: Underground energy storage and geothermal applications. Renew. Sustain. Energy Rev. 2019, 108, 498-512. [CrossRef]

27. Hall, A.; Scott, J.A.; Shang, H. Geothermal energy recovery from underground mines. Renew. Sustain. Energy Rev. 2011, 15, 916-924. [CrossRef]

28. Esteves, A.F.; Santos, F.M.; Pires, J.C.M. Carbon dioxide as geothermal working fluid: An overview. Renew. Sustain. Energy Rev. 2019, 114, 1-8. [CrossRef]

29. Shi, Y.; Song, X.; Wang, G.; McLennan, J.; Forbes, B.; Li, X.; Li, J. Study on wellbore fluid flow and heat transfer of a multilateral-well CO2 enhanced geothermal system. Appl. Energy 2019, 249, 14-27. [CrossRef]

30. Cheng, W.L.; Li, T.T.; Nian, Y.L.; Xie, K. Evaluation of working fluids for geothermal power generation from abandoned oil wells. Appl. Energy 2014, 118, 238-245. [CrossRef]

31. Van Erdeweghe, S.; Van Bael, J.; Laenen, B.; D'haeseleer, W. Design and off-design optimization procedure for low-temperature geothermal organic Rankine cycles. Appl. Energy 2019, 242, 716-731. [CrossRef]

32. Sowiżdżał, A. Geothermal energy resources in Poland-Overview of the current state of knowledge. Renew. Sustain. Energy Rev. 2018, 82, 4020-4027. [CrossRef]

33. Huculak, M.; Jarczewski, W.; Dej, M. Economic aspects of the use of deep geothermal heat in district heating in Poland. Renew. Sustain. Energy Rev. 2015, 49, 29-40. [CrossRef]

34. Faizal, M.; Bouazza, A.; Singh, R.M. Heat transfer enhancement of geothermal energy piles. Renew. Sustain. Energy Rev. 2016, 57, 16-33. [CrossRef]

35. Gonet, A.; Sapińska-Śliwa, A.; Kowalski, T.; Sliwa, T.; Bieda, A. Drilling of geothermal boreholes and casing design in Poland. In Proceedings of the European Geothermal Congress 2016, Strasbourg, France, 19-24 September 2016.

36. Biernat, H.; Kulik, S.; Noga, B. Problemy związane z eksploatacją ciepłowni geotermalnych wykorzystujacych wody termalne z kolektorów porowych (Problems associated with exploitation geothermal plants to use thermal water with rock pores). Tech. Poszuk. Geol. Geoterm. Zrównoważony Rozw. 2010, 1-2, 17-28. (In Polish)

37. Biernat, H.; Noga, B.; Kosma, Z. Przegląd konstrukcji archiwalnych i nowych otworów wiertniczych na Niżu Polskim w celu pozyskania energii geotermalnej (Review of archival and new wells constructions located in polish lowlands in order to raise a geothermal Energy). Modelowanie Inż. 2012, 44, 21-28. (In Polish)

38. Sapińska-Śliwa, A.; Biernat, H.; Sliwa, T.; Noga, B. Konstrukcje otworów geotermalnych w Polsce (Geothermal wells construction in Poland). In Proceedings of the Prezentacja IV Ogólnopolski Kongres Geotermalny (Proceedings IV Polish Geothermal Congress), Zakopane, Poland, 30 September-2 October 2013. (In Polish). 
39. Kępińska, B.; Bujakowski, W.; Bielec, B.; Tomaszewska, B.; Banaś, J.; Solarski, W.; Mazurkiewicz, B.; Pawlikowski, M.; Pająk, L.; Miecznik, M.; et al. Wytyczne Projektowe Poprawy Chłonności Skat Zbiornikowych w Związku z Zatłaczaniem Wód Termalnych w Polskich Zakładach Geotermalnych (Design Guidelines for Improving the Injectivity of Reservoir Rocks in Connection with Geothermal Water Injection in Polish Geothermal Plants); Wydawnictwo EJB: Krakow, Poland, 2011. (In Polish)

40. Koons, B.E.; Free, D.L.; Frederick, A.F. New design guidelines for geothermal cement slurries. Geotherm. Resour. Counc. Trans. 1993, 17, 43-51.

41. Gaurina-Medimurec, N.; Matanović, D.; Krklec, G. Cement slurries for geothermal wells cementing. Rud. Geol. Naft. Zb. 1994, 6, 127-134.

42. Barlet-Gouedard, V.; Vidick, B. A non-conventional way of developing cement slurry for geothermal wells. Geotherm. Resour. Counc. Trans. 2001, 25, 85-91.

43. Bett, E.K. Geothermall well cementing, materials and placement techniques. Geotherm. Train. Programme 2010, 10, 99-130.

44. Czy Mamy Potencjał Energii Geotermalnej w Polsce? (Do We Have A Potential of Geothermal Energy in Poland?)—Materiały z Seminarium Eksperckiego. Available online: http://www.mos.gov.pl/artykul/4465_aktualnosci/23476_czy_mamy_potencjal_ energii_geotermalnej_w_polsce_materialy_z_seminarium_eksperckiego.html (accessed on 10 January 2018).

45. Biernat, H. Wykorzystanie wód geotermalnych w ciepłowni w Pyrzycach (Geothermal waters utilization in the Pyrzyce power plant). Tech. Poszuk. Geol. Geosynop. Geoterm. 1993, 5-6, 99-103. (In Polish)

46. Bujakowski, W.; Bielec, B.; Miecznik, M.; Pajak, L. Reconstruction of geothermal boreholes in Poland. Geotherm. Energy 2020, 8 , 1-27. [CrossRef]

47. Bujakowski, F. Modelowanie równowagi termodynamicznych wód z horyzontu dolno jurajskiego ujętych w odwiercie geotermalnym Gostynin GT-1 (Thermodynamic equilibrium modelling of groundwater from Lower Jurassic aquifier explored in Gostynin GT-1 geothermal borehole). Prz. Nauk. Inż. Kształt. Sr. 2010, 3, 63-74. (In Polish)

48. Bujakowski, W.; Bielec, B.; Graczyk, S.; Hołojuch, G.; Kęińska, B.; Pająk, L. Projekt prac geologicznych w celu aktualizacji zasobów eksploatacyjnych wód termalnych dla otworu Poręba Wielka IG-1 (Geological Project to Update the Exploitation Resources of Geothermal Waters for the Poręba Wielka IG-1 Well); IGSMiE PAN: Krakow, Poland, 2010. (In Polish)

49. Chowaniec, J. Dotychczasowy stan rozwoju geotermii w Polsce i naturalne warunki jej rozwoju (The current state of geothermal development in Poland and natural conditions for its development). In Proceedings of the XLIII Forum, Energia-EfektŚrodowisko" (XLIII Forum “Energy-Effect-Environment"), Warsaw, Poland, 24 August 2012. (In Polish).

50. Chowaniec, J. Potencjał geotermiczny Polski w świetle uwarunkowań geologicznych (Poland's geothermal potential in the light of geological conditions). In Proceedings of the Materiały z Seminarium Eksperckiego "Czy mamy potencjał energii geotermalnej w Polsce?", (Materials from the Expert Seminar "Do we have the potential of geothermal energy in Poland?), Warsaw, Poland, 1-3 October 2014. (In Polish).

51. Prace Państwowego Instytutu Geologicznego-Państwowego Instytutu Badawczego w zakresie rozpoznawania i dokumentowania wód termalnych (geotermalnych) w Polsce (51st Works of the Polish Geological Institute-National Research Institute in the Field of Recognition and Documentation of Thermal (Geothermal) Waters in Poland). Available online: https://www.pgi.gov.pl/ dokumenty-przegladarka/aktualnosci-2016/kongres-geotermalny/4109-kongres-geotermalny-chowaniec-j-prace-pig-pib-wzakresie-rozpoznawania-i-dokumentowania-wod-termalnych-geotermalnych-w-polsce/file.html (accessed on 10 January 2018).

52. Chowaniec, J. Prace Państwowego Instytutu Geologicznego-Państwowego Instytutu Badawczego w zakresie rozpoznawania i dokumentowania wód termalnych (geotermalnych) w Polsce (The Works of the Polish Geological Institute in Recognizing and Documenting Thermal (Geothermal) Waters in Poland). Tech. Poszuk. Geol. Geoterm. Zrównoważony Rozw. 2016, 1, 197-203. (In Polish)

53. Jaromin, A.; Kepińska, B.; Nagel, J.; Sokołowski, J.; Wieczorek, J. Dokumentacja geosynoptyczna otworu geotermalnego Biały Dunajec PAN-1 (Geosynoptical documentation of the Biały Dunajec PAN-1 geothermal borehole). In Geosynoptyka i Geotermia; Tom 2; IGSMiE PAN: Kraków, Poland, 1992. (In Polish)

54. Jaromin, A.; Kępińska, B.; Nagel, J.; Sokołowski, J.; Wieczorek, J. Dokumentacja geosynoptyczna otworu geotermalnego Poronin PAN-1 (Geosynoptical documentation of the Poronin PAN-1 geothermal borehole). In Geosynoptyka i Geotermia; Tom 3; IGSMiE PAN: Kraków, Poland, 1992. (In Polish)

55. Jasnos, K.; Kołba, P.; Biernat, H.; Noga, B. Wyniki badań hydrogeologicznych prowadzących do rozpoznania i udostępniania zasobów wód termalnych na terenie gminy Kleszczów (The results of the hydrogeological research leading to know and develop the resources of thermal water in the Kleszczów district). Modelowanie Inż. 2012, 45, 64-69. (In Polish)

56. Kaczmarczyk, M.; Kaczmarczyk, M. Analysis of Possibilities for Electricity Production from Geothermal Waters in the Province of Małopolska, Poland. In Proceedings of the World Geothermal Congress 2015, Melbourne, Australia, 19-25 April 2015.

57. Kaliński, R. Wykorzystanie wody i energii geotermalnej w Uniejowie (The use of water and geothermal energy in Uniejów). In Proceedings of the Materiały z seminarium eksperckiego "Stan aktualny i perspektywy dalszego rozwoju, Czy mamy potencjał energii geotermalnej w Polsce?" (Materials from the Expert Seminar "Current State and Prospects for Further Development, Do We Have the Potential of Geothermal Energy in Poland?"), Warsaw, Poland, 1-3 October 2014. (In Polish).

58. Kępińska, B. Geothermal resources and utilization in Poland and Europe. Reports 2003. Geotherm. Train. Programme 2004, 2, 1-92.

59. Kępińska, B.; Ciagło, J. Możliwości zagospodarowania wód geotermalnych Podhala do celów balneoterapeutycznych i rekreacyjnych (Possibilities of use of the Podhale geothermal waters for balneotherapeutical and recreational purposes). Geologia 2008, 34, 541-559. (In Polish) 
60. Kleszcz, A.; Tomaszewska, B. Prognozowanie Scalingu na przykładzie wód ujmowanych otworem Bańska PGP-1 (Prediction of scaling phenomenon based on Bańska PGP-1 geothermal well). Tech. Poszuk. Geol. Geoterm. Zrównoważony Rozw. 2013, 1, 115-122. (In Polish)

61. Korzec, K.; Kmiecik, E.; Mika, A.; Tomaszewska, B.; Wątor, K. Metodyka opróbowania ujęć wód termalnych-Aspekty techniczne (Metodology of thermal water sampling-Technical aspects). Tech. Poszuk. Geol. Geoterm. Zrównoważony Rozw. 2016, 1, 75-87. (In Polish)

62. Latour, T.; Drobnik, M. Możliwości wykorzystania wód termalnych występujących na terenie Wielkopolski do celów leczniczych i rekreacyjnych (Thermal waters in the Wielkopolska region and possibilities of their use for therapeutics and recreation). Prz. Geol. 2010, 58, 609-612. (In Polish)

63. Noga, B.; Biernat, H.; Kapuściński, J.; Martyka, P. Analiza parametrów otworów geotermalnych wykonanych na Niżu Polskim pod kątem możliwości budowy siłowni binarnych wykorzystujacych ciepło wnętrza Ziemi (Analysis of parameters of geothermal well located on Polish Lowlands for the possibility of building the binary power plants which are using the heat from inside the earth). Tech. Poszuk. Geol. Geoterm. Zrównoważony Rozw. 2013, 2, 127-139. (In Polish)

64. Noga, B.; Biernat, H.; Kapuściński, J.; Martyka, P.; Nowak, K.; Pijewski, G. Perspektywy zwięsszenia pozyskiwania ciepła geotermalnego w świetle nowych inwestycji zrealizowanych na terenie Niżu Polskiego (Possibility of obtaining more geothermal heat in the view of the new investments completed on Polish Lowland). Tech. Poszuk. Geol. Geoterm. Zrównoważony Rozw. 2013, 2, 75-84. (In Polish)

65. Pratkowski, W.; Biernat, H.; Noga, B. Wyniki badań zmierzajacych do rozpoznania i udokumentowania wód termalnych w rejonie miejscowości Celejów (Research Results aimed at identifying and documenting thermal waters in the region of Celejów). Tech. Poszuk. Geol. Geoterm. Zrównoważony Rozw. 2016, 2, 33-43. (In Polish)

66. Sapińska-Śliwa, A. Technologiczne i Ekonomiczne Zagadnienia Zagospodarowania Wody Termalnej na Przykładzie Uniejowa (Technological and Economic Issues Relating to Thermal Water Utilisation with the Use of an Example of Uniejów); Wydawnictwa AGH: Kraków, Poland, 2010. (In Polish)

67. Sokołowski, J. Dokumentacja geosynoptyczna otworu geotermalnego Bańska IG-1 (Geosynoptical documentation of the Banska IG-1 geothermal borehole). In Geosynoptyka i Geotermia; Tom 1; CPPGSMiE PAN: Kraków, Poland, 1992. (In Polish)

68. Ślimak, C.; Okularczyk, B. Energia geotermalna w praktyce, 20 lat doświadczeń PEC Geotermia Podhalańska (Geothermal energy in practice, 20 years of PEC Geotermia Podhalańska experience). In Proceedings of the Materiały z Seminarium Eksperckiego "Czy mamy potencjał energii geotermalnej w Polsce?" (Materials from the Expert Seminar "Do We Have the Potential of Geothermal Energy in Poland?"), Warsaw, Poland, 1-3 October 2014. (In Polish).

69. Tomaszewska, B. Uzdatnianie wód termalnych ujętych otworem Bańska IG-1 do celów pitnych jako jeden z kierunków ich kompleksowego wykorzystania (Treatment of geothermal water from Banska IG-1 well to produce drinking water as one of directions of its wide use). Prz. Geol. 2009, 57, 21-28. (In Polish)

70. Tomczyk, B. Analiza możliwości technicznych wykorzystania energii wód geotermalnych do produkcji energii elektrycznej dla otworu Bańska PGP-3 (Analysis of the technical possibilities in using geothermal energy FOR electricity generation for the Banska PGP-3 borehole). Tech. Poszuk. Geol. Geoterm. Zrównoważony Rozw. 2016, 2, 117-134. (In Polish)

71. Uliasz-Misiak, B.; Dubiel, S. Problemy rekonstrukcji odwiertów geotermalnych (Problems of geothermal wells workover operations). Prz. Gór. 2015, 7, 55-61. (In Polish)

72. Wardzała, M.; Kilar, J. Doświadczenia Uzyskane Przez PNIG Jasło w Trakcie Wykonywania Otworów Geotermalnych w Latach 1990-2008 (Experiences Obtained by PNIG Jasło while Drilling Geothermal Wells in 1990-2008), in. Praca Zbiorowa, "Konferencja NaukowoTechniczna-Wiercenia Geotermalne Nowe Technologie Wiercenia i Udostępniania Wód Geotermalnych Oraz Perspektywy Wykorzystania Energii Geotermalnej w Świetle Polityki Energetycznej Kraju" (Collective Work "Scientific and Technical Conference-Geothermal Drilling New Technologies for Drilling and Sharing Geothermal Waters and Prospects for Using Geothermal Energy in the Light of the Country's Energy Policy"); Stowarzyszenie Naukowo-Techniczne Inżynierów i Techników Przemysłu Naftowego i Gazowniczego: Krasiczyn, Polska, 2009; pp. 85-121. (In Polish)

73. Wartak, W. Geothermal heating in Podhale-project implemented with the financial support of the Ministry of Foreign Affairs of the Republic of Poland under the Polish development cooperation program. In Proceedings of the International Seminar Titled: Improvement of Energy Management in Typical Public Buildings of the City and Oblast Ivano-Frankivsk, Zakopane, Poland, 9-12 August 2013. (In Ukrainian).

74. Liber-Makowska, E.; Łukaczyński, I. Charakterystyka nowo rozpoznanego złoża wód termalnych w Karpnikach na tle warunków geotermicznych Kotliny Jeleniogórskiej (Characteristics of newly recognized deposit of thermal waters in Karpniki on the background of the geothermical conditions of Jelenia Góra valley). Tech. Poszuk. Geol. Geoterm. Zrównoważony Rozw. 2016, 2, 5-16. (In Polish)

75. Firma G-Drilling. Geothermal Wells. Available online: http://www.g-drilling.pl/realizacje/otwory-geotermalne/ (accessed on 10 March 2020). (In Polish).

76. Wybrane Otwory Wiertnicze (Selected Wells). Available online: http://otworywiertnicze.pgi.gov.pl/ (accessed on 15 December 2019). (In Polish)

77. Chowaniec, J.; Poprawa, D.; Witek, K. Występowanie wód termalnych w polskiej części Karpat (Occurrence of thermal waters in the Polish part of the Carpathians). Prz. Geol. 2001, 49, 734-742. (In Polish) 
78. Dobrzyński, D.; Gruszczyński, T.; Birski, Ł. German jako wskaźnik warunków hydrogeochemicznych w jeleniogórskim systemie geotermalnym (Germanium as an indicator of hydrogeochemical conditions in the Jelenia Góra Geothermal System). Prz. Geol. 2017, 65, 946-950. (In Polish)

79. Fistek, J. Wykorzystanie wód termalnych w uzdrowiskach sudeckich Polski (Thermal water use in health resorts of the Sudety Mountains in Poland). Tech. Poszuk. Geol. 2008, 47, 3-16. (In Polish)

80. Szafrański, M. Geotermia-Szansa czy kłopot (Geothermal energy-Chance or trouble). Prz. Koniń. Dod. Prz. Koniń. 2019, 26, 2-3. (In Polish)

81. Kazimierza Wielka-Budowa Pierwszego w Polsce Otwartego Termalnego Basenu Siarczkowego! (Kazimierza WielkaConstruction of the First Open Thermal Sulphide Pool in Poland!). Available online: www.globenergia.pl/magazyn/ kazimierza-wielka-budowa-pierwszego-w-polsce-otwartego-termalnego-basenu-siarczkowego/ (accessed on 15 December 2019). (In Polish).

82. Firma Pro-Invest Solution. Available online: https://proinsol.pl/portfolio-item/sieradz/ (accessed on 15 December 2019).

83. Ponad 13 Mln zł na Geotermię w Tomaszowie! (Over PLN 13 Million for Geothermal Energy in Tomaszów!). Available online: http:/ / www.tomaszow-maz.pl/aktualnosci/-ponad-13-mln-zl-na-geotermie-w-tomaszowie/ (accessed on 27 January 2020). (In Polish).

84. Geotermia-Szansa czy Kłopot? (Geothermal energy-Opportunity or Trouble?). Available online: https://www.mpec.konin.pl/ index.php/aktualnosci-jedna/geotermiaszansaczyklopot.html (accessed on 5 March 2020). (In Polish).

85. Gmina Jaworze (Jaworze Commune). Available online: https://www.slaskie.pl/download/content/66109 (accessed on 27 January 2020). (In Polish).

86. Otwory Wiertnicze (Drilling Boreholes). Available online: https: $/ /$ mineralne.pgi.gov.pl $/$ component $/ \mathrm{kgm} /$ ?oc=1\&template= pgiblank\&lang=pl (accessed on 21 January 2020). (In Polish)

87. Kęińska, B. Geothermal Energy Country Update Report from Poland, 2015-2019. In Proceedings of the World Geothermal Congress 2020, Reykjavik, Iceland, 26 April-2 May 2020. Available online: https:/ / pangea.stanford.edu/ERE/db/IGAstandard/ record_detail.php?id=29373 (accessed on 23 April 2021).

88. Hajto, M. United Nations Framework Classification of Geothermal Resources (UNFC-2009) against the Polish classification and methodology of geothermal resources assessment. Tech. Poszuk. Geol. Geoterm. Zrównoważony Rozw. 2016, 1, 129-142. Available online: https://min-pan.krakow.pl/ / wydawnictwo/wp-content/uploads/sites/4/2017/12/11-Hajto.pdf (accessed on 27 January 2020). (In Polish).

89. Gonet, A.; Sliwa, T.; Stryczek, S.; Sapińska-Śliwa, A.; Jaszczur, M.; Pająk, L.; Złotkowski, A. Metodyka Identyfikacji Potencjału Cieplnego Górotworu Wraz z Technologią Wykonywania i Eksploatacji Otworowych Wymienników Ciepła (Methodology for the Identification of Potential Heat of the Rock Mass Along with Technology Implementation and Operation of the Borehole Heat Exchangers); Wydawnictwa AGH: Kraków, Poland, 2011. (In Polish)

90. Sliwa, T.; Gonet, A.; Sapińska-Śliwa, A.; Złotkowski, A. Laboratorium Geoenergetyki-10 lat działalności na Akademii GórniczoHutniczej w Krakowie (Geoenergetics Laboratory-10 years of activity at the AGH University of Science and Technology in Krakow). Tech. Poszuk. Geol. Geoterm. Zrównoważony Rozw. 2018, 1, 141-163. (In Polish)

91. Sliwa, T.; Sapinska-Sliwa, A.; Wiśniowski, R.; Piechówka, Z.; Krzemień, M.; Pycha, D.; Jaszczur, M. Influence of flow rate and heating power in effective thermal conductivity applied in borehole heat exchangers. J. Phys. Conf. Ser. 2016, 745, 1-8. [CrossRef]

92. Lee, C.; Moonseo, P.; Min, S.; Kang, S.H.; Sohn, B.; Choi, H. Comparison of effective thermal conductivity in closed-loop vertical ground heat exchangers. Appl. Therm. Eng. 2011, 31, 3669-3676. [CrossRef]

93. Sliwa, T.; Sowa, M.; Stryczek, S.; Gonet, A.; Złotkowski, A.; Sapińska-Śliwa, A.; Knez, D. Badania stwardniałych zaczynów cementowych z dodatkiem grafitu (The study of hardened cement slurries with addition of graphite). Wiert. Naft. Gaz 2011, 28, 571-583. (In Polish)

94. Delaleux, F.; Py, X.; Olives, R.; Dominguez, R. Enhancement of geothermal borehole heat exchangers performances by improvement of bentonite grouts conductivity. Appl. Therm. Eng. 2012, 33-34, 92-99. [CrossRef]

95. Sliwa, T.; Kowalski, T.; Stryczek, S.; Wiśniowski, D.; Bieda, A.; Piwowarczyk, S.; Beszłej, J.; Naklicki, M.; Sapińska-Śliwa, A. The impact of graphite on the thermal conductivity of solidified grout. AGH Drill. Oil Gas 2017, 34, 811-820. [CrossRef]

96. Sapińska-Śliwa, A.; Sliwa, T.; Wiśniowski, R. Grafit i diatomit jako dodatki do zaczynów uszczelniających otwory w geotermii (Graphite and diatomite as additives for grouts for boreholes in geothermics). Przem. Chem. 2017, 96, 1723-1725. (In Polish) [CrossRef]

97. Sliwa, T.; Stryczek, S.; Wysogląd, T.; Skakuj, A.; Wiśniowski, R.; Sapińska-Śliwa, A.; Bieda, A.; Kowalski, T. Wpływ grafitu i diatomitu na parametry wytrzymałościowe stwardniałych zaczynów cementowych (Impact of graphite and diatomite on the strength parameters of hardened cement slurries). Przem. Chem. 2017, 96, 960-963. (In Polish) [CrossRef]

98. Shirazi, S.A.; Bernier, M. A small-scale experimental apparatus to study heat transfer in the vicinity of geothermal boreholes. HVACER Res. 2014, 20, 819-827.

99. Lamarche, L.; Beauchamp, B. New solutions for the short-time analysis of geothermal vertical boreholes. Int. J. Heat Mass Transf. 2007, 50, 1408-1419. [CrossRef]

100. Lamarche, L. Short-time analysis of vertical boreholes, new analytic solutions and choice of equivalent radius. Int. J. Heat Mass Transf. 2015, 91, 800-807. [CrossRef] 
101. Nian, Y.L.; Cheng, W.L. Analytical g-function for vertical geothermal boreholes with effect of borehole heat capacity. Appl. Therm. Eng. 2018, 140, 733-744. [CrossRef]

102. Sliwa, T.; Sapińska-Śliwa, A.; Knez, D.; Bieda, A.; Kowalski, T.; Złotkowski, A. Borehole Heat Exchangers: Production and Storage of Heat in the Rock Mass; Laboratory of Geoenergetics Book Series; Drilling, Oil and Gas Foundation: Krakow, Poland, 2016; Volume 2.

103. Sliwa, T.; Kruszewski, M.; Zare, A.; Assadi, M.; Sapińska-Śliwa, A. Potential application of vacuum insulated tubing for deep borehole heat exchangers. Geothermics 2018, 75, 58-67. [CrossRef]

104. Sliwa, T.; Sojczyńska, A.; Rosen, M.A.; Kowalski, T. Evaluation of temperature profiling quality in determining energy efficiencies of borehole heat exchangers. Geothermics 2019, 78, 129-137. [CrossRef]

105. Somerton, W.H. Thermal Properties and Temperature-Related Behavior of Rock/Fluid Systems, 1st ed.; Elsevier: Amsterdam, The Netherlands, 1992.

106. Hermanns, M.; Ibanez, S. Thermal Response of Slender Geothermal Boreholes to Subannual Harmonic Excitations. SIAM J. Appl. Math. 2019, 79, 230-256. [CrossRef]

107. Barthel, P. Einsatz von Geoinformationssystemen (GIS) zur geologischen Standortbewertung, zur Analyse des regionalen Potentials und als Planungshilfsmittel für die thermische Nutzung des flachen Untergrundes bis $200 \mathrm{~m}$ Tiefe als Wärmequelle und Wärmespeicher in Unterfranken/Bayern. Ph.D. Thesis, Bayerischen Julius-Maximilians-Universität Würzburg, Würzburg, Germany, 2000. (In German).

108. Bieda, A.; Kowalski, T.; Sliwa, T.; Skowroński, D.; Kowalska-Kubsik, I.; Rado, R. Udarowo-obrotowa metoda wiercenia otworowych wymienników ciepła jako alternatywa wiertnicza przyjazna środowisku (Rotary-percussion drilling for borehole heat exchangers as an environmentally friendly drilling alternative). Przem. Chem. 2018, 97, 864-986. (In Polish) [CrossRef]

109. Sliwa, T.; Rosen, M.A. Efficiency analysis of borehole heat exchangers as grout varies via thermal response test simulations. Geothermics 2017, 69, 132-138. [CrossRef]

110. Sapińska-Śliwa, A. Efektywność Pozyskiwania Ciepła z Górotworu w Aspekcie Sposobu Udostępniania Otworami Wiertniczymi (Effectiveness of Heat Recovery from Rock Mass in the Context of the Production Method by Means of Boreholes); Rozprawy Monografie Akademia Górniczo-Hutnicza im. Stanisława Staszica w Krakowie nr 364; Wydawnictwa AGH: Krakow, Poland, 2019. (In Polish)

111. Sapińska-Śliwa, A.; Rosen, M.A.; Gonet, A.; Sliwa, T. Deep borehole heat exchangers-A conceptual and comparative review. Int. J. Air-Cond. Refrig. 2016, 24, 1-15. [CrossRef]

112. Sliwa, T.; Kotyza, J. Dobór optymalnego otworowego wymiennika ciepła w otworze Jachówka $2 \mathrm{~K}$ do głębokości $2870 \mathrm{~m}$ (Selection of optimal construction of borehole heat exchangers based on Jachówka 2K well to a depth $2870 \mathrm{~m}$ ). In Metodyka $i$ technologia uzyskiwania użytecznej energii geotermicznej z pojedynczego otworu wiertniczego (Methodology and Technology of Obtaining Useful Geothermal Energy from a Single Borehole); Sokołowski, J., Ed.; Polgeotermia-PGA-IPPGSMiE PAN: Kraków, Poland, 2000. (In Polish)

113. Schneider, D.; Strotköffer, T.; Broßmann, E. Die 2800 m von Prenzlau oder die tiefste Erdwärmesonde der Welt. Geotherm. Energ. 1996, 16, 10-12. (In German)

114. Zagórski, J. Krótkie wieści z kraju i ze świata. Ilość wierceń na świecie rośnie (Short news from the country and the world. The number of drillings in the world is increasing). Wiad. Naft. Gazow. 2018, 10, 240. (In Polish) 